\title{
Recent applications of the divinylcyclopropane-cycloheptadiene rearrangement in organic synthesis
}

Sebastian Krüger and Tanja Gaich ${ }^{*}$

\author{
Review \\ Address: \\ Institut für Organische Chemie, Leibniz Universität Hannover, \\ Schneiderberg 1B, 30167 Hannover, Germany \\ Email: \\ Tanja Gaich* - tanja.gaich@oci.uni-hannover.de \\ * Corresponding author \\ Keywords: \\ cycloheptadiene; divinylcyclopropane rearrangement; domino \\ reactions; natural products; total synthesis; \\ vinylcyclopropane-carbaldehyde rearrangement
}

\author{
Beilstein J. Org. Chem. 2014, 10, 163-193. \\ doi:10.3762/bjoc. 10.14
}

Received: 20 August 2013

Accepted: 11 November 2013

Published: 16 January 2014

This article is part of the Thematic Series "Natural products in synthesis and biosynthesis".

Guest Editor: J. S. Dickschat

(C) 2014 Krüger and Gaich; licensee Beilstein-Institut.

License and terms: see end of document.

\begin{abstract}
This review summarizes the application of the divinylcyclopropane-cycloheptadiene rearrangement in synthetic organic chemistry. A brief overview of the new mechanistic insights concerning the title reaction is provided as well as a condensed account on the biological relevance of the topic. Heteroatom variants of this rearrangement are covered briefly.
\end{abstract}

\section{Introduction}

The first documented divinylcyclopropane-cycloheptadiene rearrangement dates back to 1960 occuring during studies of Vogel and coworkers [1,2] on the thermal rearrangement of small carbocycles. Although the desired cis-divinylcyclopropane (9) (see Scheme 1) could not be isolated using the depicted synthetic route (see $\mathbf{1}$ to $\mathbf{1 0}$ ), as $\mathbf{9}$ readily rearranged under the final Hofmann elimination conditions, the resulting cycloheptadiene $\mathbf{1 0}$ was described as well as the rearrangement of trans-divinylcyclopropane taking place at $200{ }^{\circ} \mathrm{C}$. The elusive $c i s$-divinylcyclopropane (9) was characterized ten years later by Brown and coworkers [3] using a low temperature and very short-timed Wittig reaction between cis-vinylcarbaldehyde 11 and methylenetriphenylphoshorane.

This review summarizes the recent synthetic applications of the divinylcyclopropane-cycloheptadiene rearrangement starting in 1991. Earlier classic syntheses of sesquiterpenes are described to underline the synthetic power in the total synthesis of sesquiterpenoid natural products. The title reaction has been subject to previous reviews [5,6], partial overlap with the 


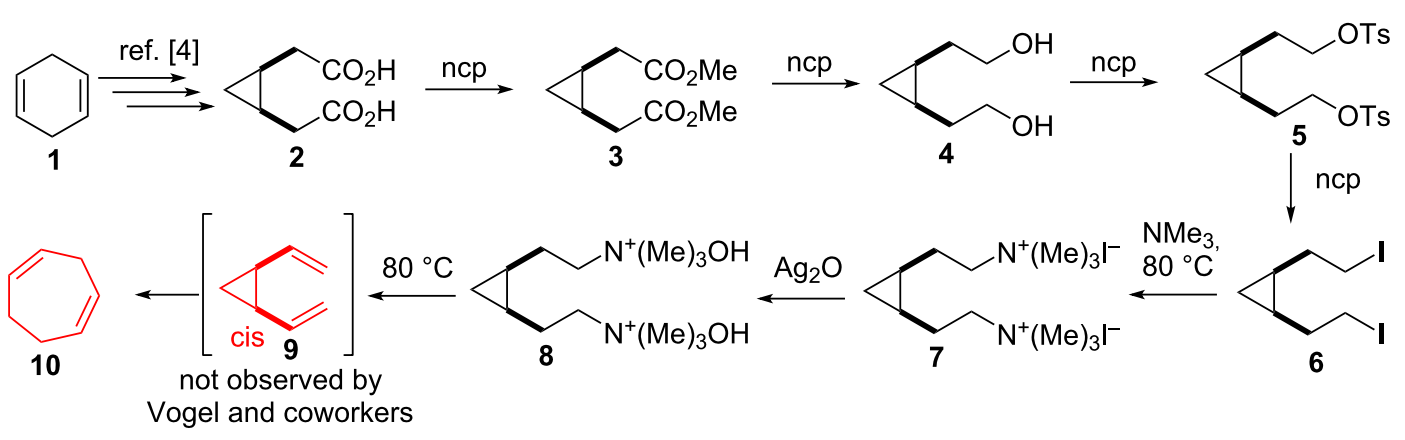

$\mathrm{H}_{2} \mathrm{CPPh}_{3}$, DMSO/isopentane, $5^{\circ} \mathrm{C}$, 1 min (addition, reaction, low temperature quench)

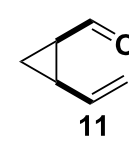
then distillation at $-40^{\circ} \mathrm{C} / 0.5 \mathrm{mmHg}$, NMR at $-20^{\circ} \mathrm{C}$

11

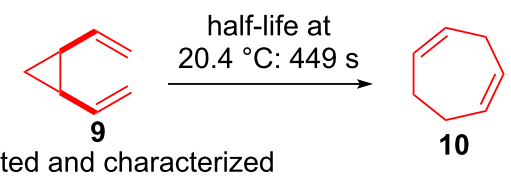

isolated and characterized
by Brown and coworkers

Scheme 1: Vogel's first approach towards the divinylcyclopropane rearrangement [4] and characterization of cis-divinylcyclopropane by Brown.

content of this review to other reviews concerning different topics exist [7-10]. The divinylcyclopropane-cycloheptadiene rearrangement will be abbreviated as DVCPR in the following. The divinylcycloproane moiety and the resulting cycloheptadiene will be highlighted in red throughout. The Buchner ring expansion $[11,12]$ as a special case of the DVCPR is not part of this review. The related vinylcylopropane-cyclopentene rearrangement has been reviewed elsewhere $[13,14]$.

\section{Review}

\section{Mechanistic considerations}

Transition state. Although the cis-divinylcyclopropane rearrangement is in fact a tethered version of the Cope rearrangement, it has to be noted that the preference of transition states (chair/boat) is opposite. Whereas the Cope rearrangement of hexa-1,5-diene 12 usually proceeds through chair-like transition state 12' (see Scheme 2) and not through

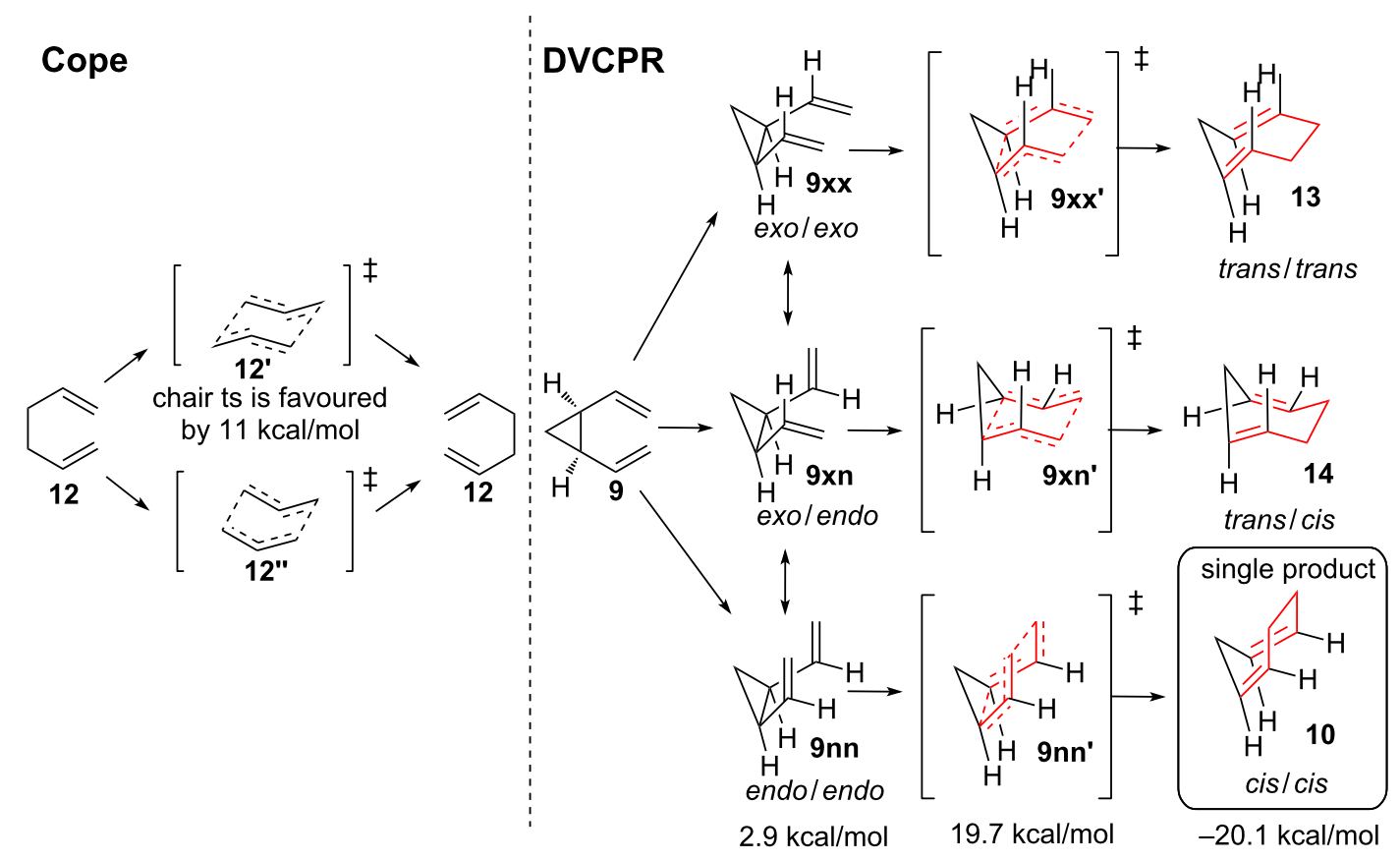

Scheme 2: Transition states for the Cope rearrangement and the related DVCPR. Ts = transition state 
the energetically disfavoured boat-transition state 12" [15], the DVCPR only proceeds via boat-like transition state 9nn' where both vinyl-moieties are in the endo-orientation reagarding the cyclopropane [16]. The other transition states $\left(\mathbf{9} \mathbf{x x}^{\mathbf{1}} / \mathbf{9} \mathbf{x n} \mathbf{n}^{\prime}\right)$ would result in a cycloheptadiene with at least one $E$-configured double bond (13/14) after a hypothetical DVCPR, which can be regarded as inaccessible. Calculations revealed that the preferred orientation for cis-divinylcyclopropane is exo/exo $\mathbf{9 x x}$. The first rotation of a vinyl-moiety into the endo-orientation requires $0.8 \mathrm{kcal} / \mathrm{mol}$ giving $9 \mathbf{x n}$, the endo-orientation of both vinyl-moities requires $2.9 \mathrm{kcal} / \mathrm{mol}$ represented as $9 \mathbf{n n}$ [17-19]. The necessary energy for the only possible transition state 9nn' results in $19.7 \mathrm{kcal} / \mathrm{mol}$, which is in good agreement with the experimental values of von Doering [20,21]. The rearranged cycloheptadiene $\mathbf{1 0}$ is favoured by $-20.1 \mathrm{kcal} / \mathrm{mol}$ compared to the corresponding cis-divinylcyclopropane (9). Calculations have been carried out for cis-divinylheterocyclopropanes including nitrogen, oxygen, sulfur and phosphorus substitution [22], as well as cis-1,2-cyclobutanes [19,23]. Earlier calculations have been carried out for mono-heteroatom substitution in the vinyl moiety $[24,25]$.

Transition state 9nn' concludes that only cis-divinylcyclopropane undergoes the desired rearrangement, whereas transdivinylcyclopropane should not react.

Trans-cis isomerization. Nevertheless, trans-divinylcyclopropane 15 (see Scheme 3) can be used in the DVCPR, as it undergoes isomerization to the desired cis-isomer 9 at elevated temperature $\left(\approx 200{ }^{\circ} \mathrm{C}[1,2]\right.$, lowered for more conjugated systems). The isomerization pathways have been suggested to proceed either via the formation of intermediate diradicalspecies (pathway A, Scheme 3) [16,20,26,27] or through onecenter epimerization (pathway B) $[28,29]$. Following pathway A, the $\mathrm{C} 1-\mathrm{C} 2$ bond of $\mathbf{1 5}$ is cleaved homolytically to give diradical 16. The two radicals are stabilized as allylic radicals (depicted as $\mathbf{1 6}^{\prime}$ ), rotation around the $\mathrm{C} 1-\mathrm{C} 3$ bond takes place (16' to 16") followed by radical recombination to give cisdivinylcyclopropane (9). Pathway B proceeds through the formation of planar allylic anion $\mathbf{1 7}$, which undergoes inversion to give cis-divinylcyclopropane (9). An alternative reaction pathway of the trans-divinylcyclopropane (15) to yield the cycloheptadiene product is the direct formation of the seven membered ring from diradical $\mathbf{1 6}$.

\section{Biosynthetic applications}

The DVCPR has been shown to be part of the biosynthesis of ectocarpene (21, see Scheme 4) [29], an inactivated algae pheromone [30,31]. Starting from all-cis-pentaenic acid (18) peroxidation is supposed to take place to give $\mathbf{1 9}$, followed by formation of the active algae pheromone $\mathbf{2 0}$ upon enzyme

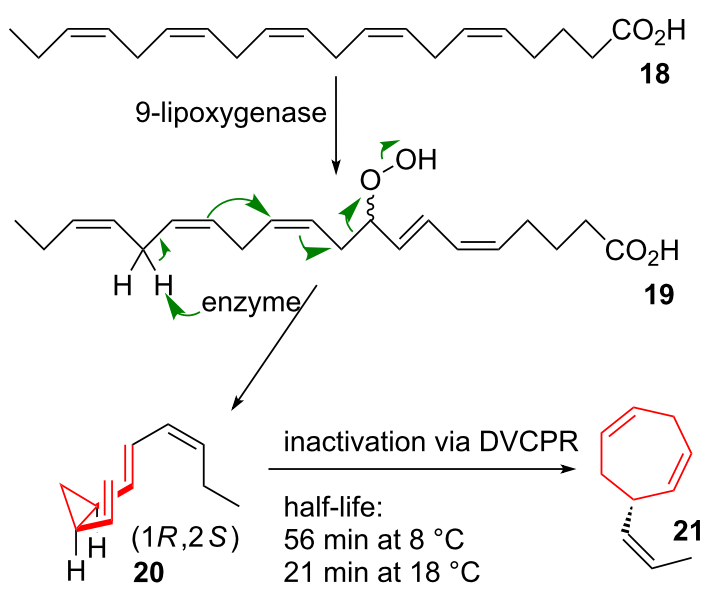

active algae pheromone

(6S)-ectocarpene

Scheme 4: Proposed biosynthesic pathway to ectocarpene (21), an inactive degradation product of a sexual pheromone of brown algae (20).

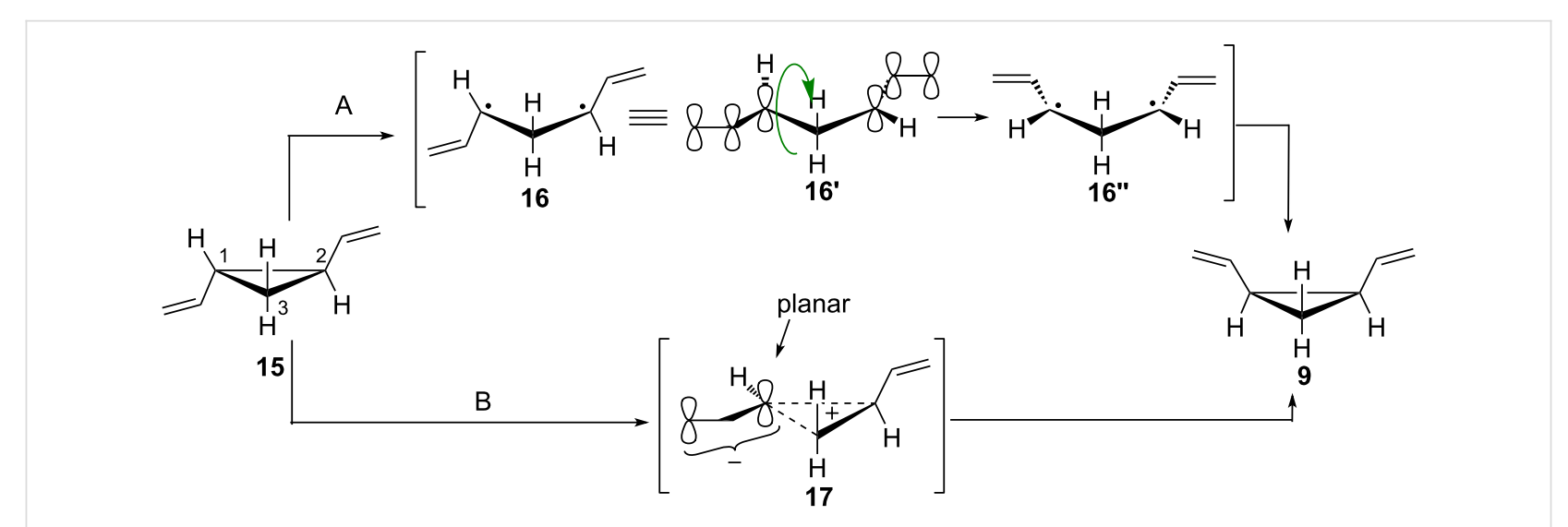

Scheme 3: Two possible mechanisms of trans-cis isomerizations of divinylcyclopropanes. 
catalyzed fragmentation. Uncatalyzed DVCPR takes places to give 21 within short periods of time. The corresponding activation energies have been determined as well as the half-lifes at different temperatures. Bioassays proved that $\mathbf{2 0}$ was far more bioactive than $\mathbf{2 1}$, and since the measured half-life for the conversion from $\mathbf{2 0}$ to $\mathbf{2 1}$ was longer than the necessary time for sexual encounter of the algae cycloheptadiene 21 was ruled out as a time-dependent sexual pheromone [32].

A divinyloxirane rearrangement has been proposed as the key step in the biosynthesis of several natural products containing a dihydrooxepine moiety. In the case of occidenol (25, see Scheme 5), which has been isolated from the wood of Thuja koraiensis, farnesyl pyrophosphate (22) is supposed to undergo ring closure and the intermediate carbocation is trapped by hydroxide to give hedycaryol (23) [33]. Oxidation leads to divinyloxirane $\mathbf{2 4}$, which rearranges to the corresponding dihydrooxepine, yielding occidenol (25) [34,35]. Miscandenin (26, isolated from Mikania species) [36] and dictyoxepin (27, isolated from brown algaes) [37] are supposed to originate from the same cis-divinyloxirane rearrangement.

Gaich et al. $[38,39]$ used the DVCPR in a biosynthetic investigation targeting the dimethylallyltryptophan synthase. In order to test the biosynthetic hypothesis of the mode of action of the 4-prenylation of indoles by Arigoni and Wenkert (starting from L-tryptophan and dimethylallyl pyrophosphate (DMAPP) through 28 to yield 29, (Scheme 6) [40-42] the spiro-oxindole 30 was synthesized. The system underwent a cis-aryl-vinylcyclopropane rearrangement [43] to give $\mathbf{3 1}$ followed by rearomatization in 4-12 hours at room temperature yielding tricycle 32. The formation of the obtained tricyclic cyclohepta $[c d]$ oxindole core $\mathbf{3 2}$ proved the synthetic versatility of a [3,3]-sigmatropic rearrangement for direct $\mathrm{C}-\mathrm{C}$-bond formation at the $\mathrm{C} 4$ position of the indole nucleus, and thus provides experimental evidence for the biosynthetic proposal.<smiles>CC#CC(C)=CCCC1=CCCC(C)=CC1PO</smiles>

farnesyl pyrophosphate (22)

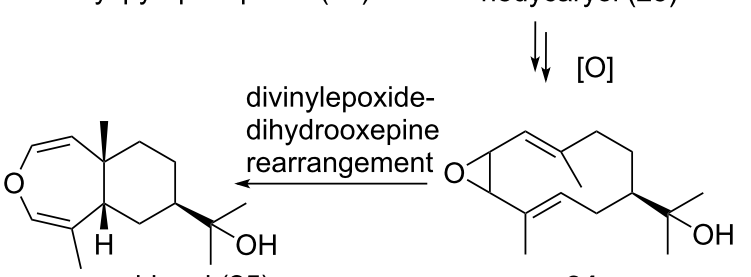<smiles>CCC=C1CC(CCC(C)(C)O)CC=C1C</smiles>

hedycaryol (23)

24<smiles>C=C1C(=O)O[C@H]2C[C@H]3C=COC=C4C(=O)OC(C14)C32C</smiles>

miscandenin (26)

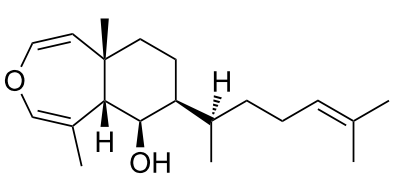

dictyoxepin (27)

Scheme 5: Proposed biosynthesis of occidenol (25) and related natural compounds.

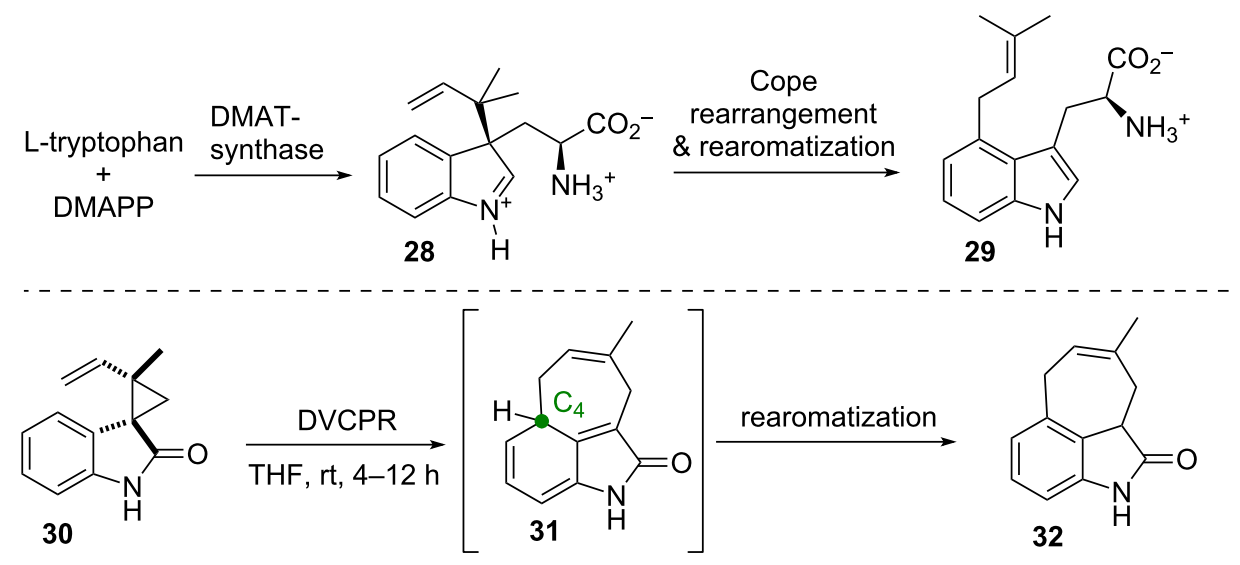




\section{Applications to natural product synthesis Fatty acid metabolites}

Iguchi and co-workers [44] applied the DVCPR to the total synthesis of the marine prostanoid clavubicyclone [45]. Known aldehyde 33 (see Scheme 7) [46] was subjected to Wittig conditions to furnish an intermediate lactone, which was then opened reductively followed by selective oxidation of the allylic alcohol to yield aldehyde 34. Addition of double deprotonated methyl acetoacetate gave $\beta$-ketoester 35. Diazotransfer followed by double protection resulted in the formation of com- pound 36. Rh-catalyzed intramolecular cyclopropanation of this compound gave bicycle 37. Selective removal of the secondary protected alcohol through $\beta$-elimination yielded trans-divinylcyclopropane 38, which underwent DVCPR under forcing conditions after trans-cis-isomerization to obtain the desired bridged bicycle 39.

Reduction of ketone 39 (see Scheme 8) introduced a new stereocenter (10:1 selectivity), which was not assigned. The resulting major alcohol was protected, followed by saponifica-

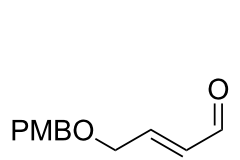

33

a. 2-triphenylphosphoranylidene- $\gamma$ butyrolactone, DCM, rt, $87 \%$

b. DIBAL-H, DCM, $-78^{\circ} \mathrm{C}$ to $0^{\circ} \mathrm{C}, 97 \%$ c. $\mathrm{MnO}_{2}, \mathrm{DCM}, \mathrm{rt}$

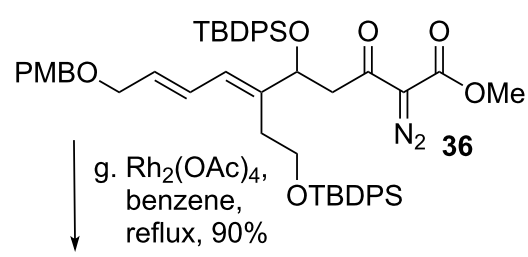

e. $\mathrm{TsN}_{3}, \mathrm{NEt}_{3}$, MeCN, rt, $89 \%$

f. TBDPSCl, imidazole, DMF, rt, $90 \%$<smiles>CCCCOCC=CC=C(C=O)CCO</smiles>

d. methyl acetoacetate, $\mathrm{NaH}, n$-BuLi, THF, $-40^{\circ} \mathrm{C}$, 63\% (two steps) reflux, $90 \%$

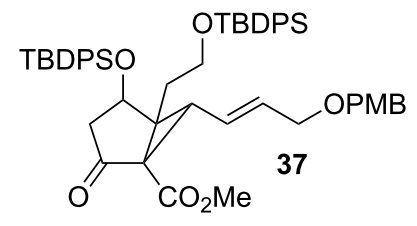
h. DBU, toluene, $70{ }^{\circ} \mathrm{C}, 89 \%$
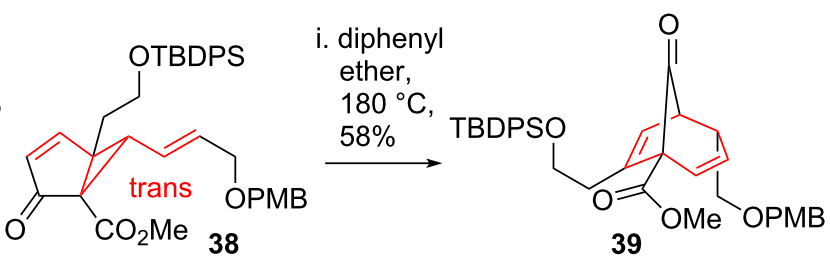

Scheme 7: Iguchi's total synthesis of clavubicyclone, part 1.

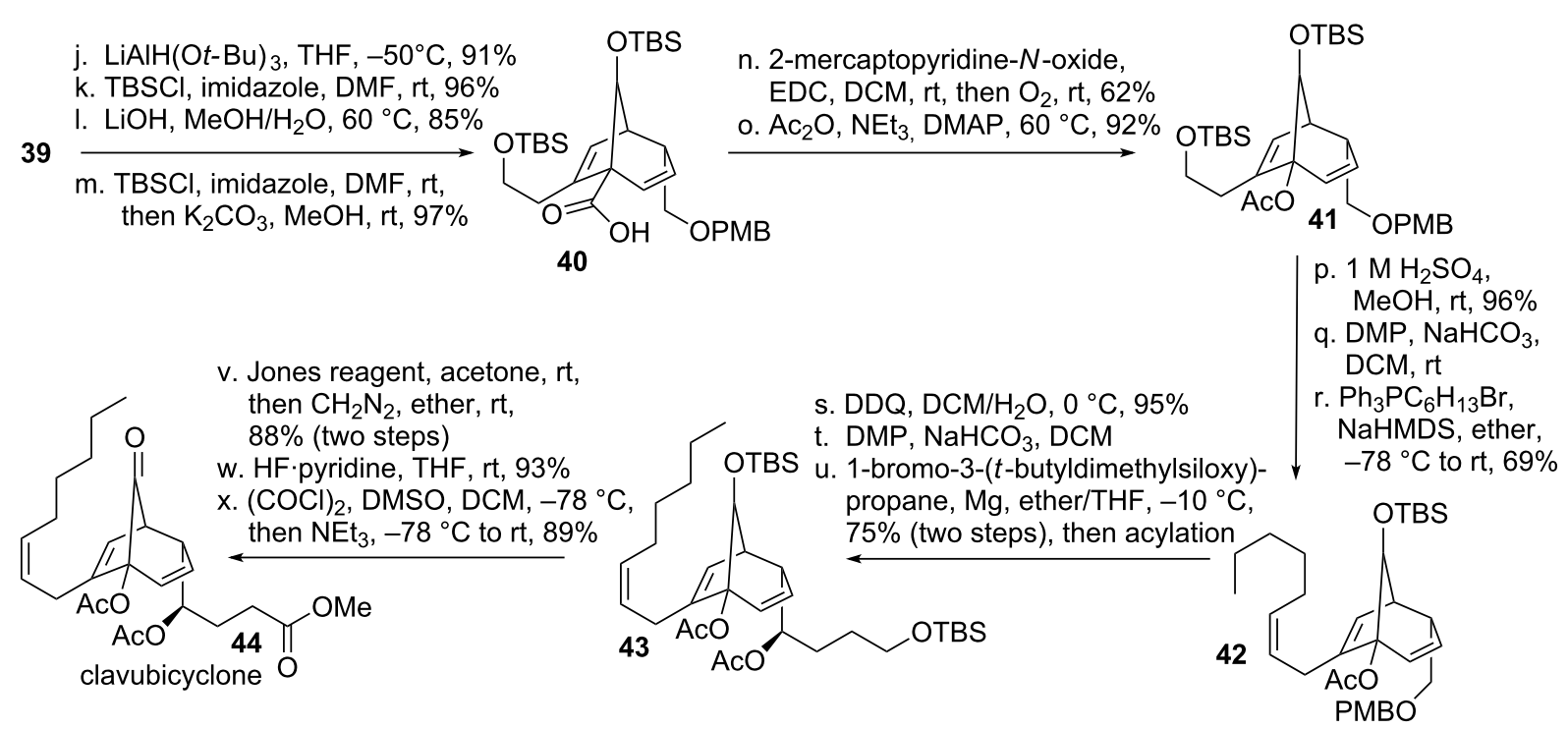

Scheme 8: Iguchi's total synthesis of clavubicyclone, part 2. 
tion of the ester with concomitant removal of the TBDPSprotecting group. The resulting free alcohol was then re-protected to give bicycle 40. Barton decarboxylation was then achieved using standard conditions, followed by trapping of the resulting carbon-centered radical with oxygen. The resulting tertiary alcohol was then protected to give acetate $\mathbf{4 1}$. Standard functional group interconversions led to the formation of the remaining side chain using Wittig-conditions to afford olefin 42. Another series of standard functional group interconversions furnished diacetate $\mathbf{4 3}$, which could be converted to the desired natural product $\mathbf{4 4}$ using a three step sequence.

\section{Terpenoid targets}

The group of Wender applied the DVCPR in their total syntheses of $( \pm)$-confertin (50) and $( \pm)$-damsinic acid (51) [47].
A mixture a trans/cis-vinylcyclopropyllithium 46 (see Scheme 9) [48] was added to ketone $\mathbf{4 5}$ followed by elimination to give a mixture of trans/cis-divinylcyclopropanes $47 / 48$. Photoepimerization at the temperature required for $c i s$-DVCPR $\left(98^{\circ} \mathrm{C}\right.$, trans-DVCPR occurred above $140{ }^{\circ} \mathrm{C}$ ) gave bicyclic 49 in good yields. $( \pm)$-Confertin (50) and $( \pm)$-damsinic acid (51) could be accessed after 10 or 7 steps respectively.

Piers and co-workers were the first to examine the DVCPR as a key step in the formal synthesis of $( \pm)$-quadrone $(\mathbf{5 5}$, see Scheme 9) [49], and the total syntheses of sinularene (59) [50], prezizanol (63) and prezizaene (64) [51]. The synthesis of the cytotoxic sesquiterpenoid quadrone (55) from Aspergillus terreus [52,53] started from tricyclic ketone $\mathbf{5 2}$ [54], which was converted into tricycle $\mathbf{5 3}$ in 12 steps. Trans-divinylcyclo-

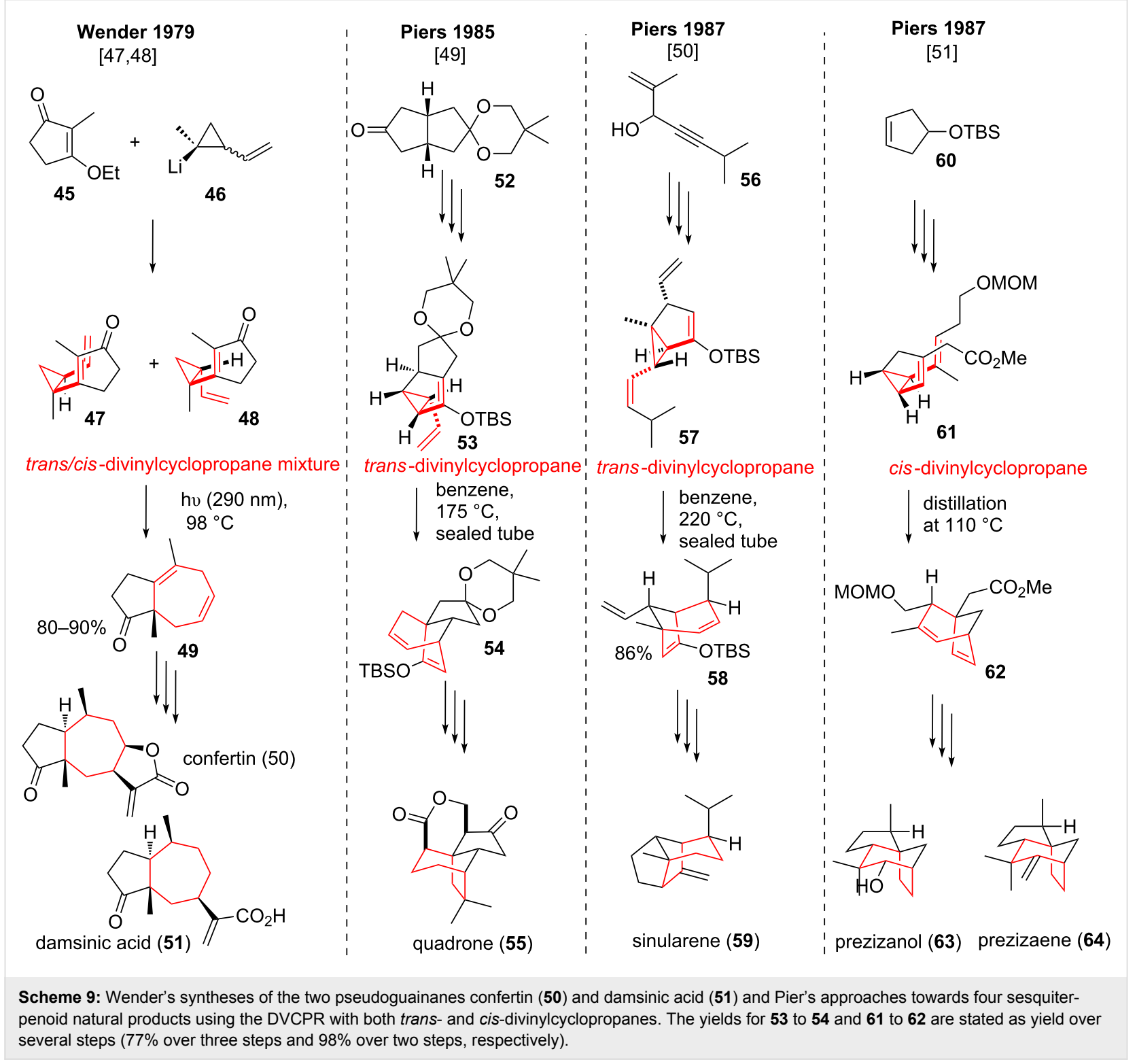


propane 53 underwent the desired DVCPR after trans-cisisomerization of the vinyl moiety at $175^{\circ} \mathrm{C}$, forming bridged tetracycle 54, which already contained the crucial sevenmembered ring present in the target molecule 55. Intermediate $\mathbf{5 4}$ was advanced in ten steps to provide an intermediate aldehyde, which had been previously converted to the natural product in seven steps [55-57].

The total synthesis of the sesquiterpenoid sinularene (59) from the coral Sinularia mayi [58] started from alcohol 56, which was converted to bicyclic 57 in nine steps. Trans-divinylcyclopropane $\mathbf{5 7}$ was then subjected to high temperature DVCPR conditions furnishing bridged bicycle 58. Trans-cis isomerization of the vinyl moiety had to take place prior to the rearrangement to access the required boat transition state of the rearrangement. Intermediate $\mathbf{5 8}$ was converted to the natural product $\mathbf{5 9}$ in four additional steps.

Two other sesquiterpenoids, prezizaene (63) $[59,60]$ and prezizanol (64) [60], isolated from Eremophilia georgei or vetiver oil were synthesized starting from cyclopentene derivative $\mathbf{6 0}$ [61]. This rather simple starting material was elaborated to advanced bicyclic $\mathbf{6 1}$ in only seven steps. This time the group of Piers used a cis-divinylcyclopropane, which underwent smooth DVCPR during distillation at $110^{\circ} \mathrm{C}$ to yield bridged bicycle 62. The desired natural products $63 / 64$ were obtained after another ten or eleven steps respectively. For more "classic" applications of the DVCPR in total synthesis see reference [5].

Overman and coworkers [62-65] successfully applied the DVCPR as the key step in their total synthesis of the diterpene scopadulcic acid B (79, see Scheme 10), isolated from the Paraguayan plant Scoparia dulcis [66]. Starting from 2-iodobenzaldehyde (65) allyl-Grignard addition took place followed by TBS-protection of the resulting alcohol. The installed double bond was subjected to hydroboration/oxidation, followed by Swern oxidation of the resulting alcohol to yield aldehyde 66. Addition of cyclopropyl-Grignard reagent 67 [67,68], followed by oxidation to the corresponding ketone yielded vinylcyclopropane 68. Deprotonation and TMS-protection furnished silyl-enolether $\mathbf{6 9}$, which underwent the desired DVCPR in almost quantitative yield at elevated temperature, followed by removal of the silyl-protecting group under acidic conditions to furnish cycloheptenone 70. Standard functional group interconversion furnished diolefin 71. Subjection of this compound to Heck coupling conditions resulted in in the formation of a bridged tetracycle after initial Heck coupling followed by carbo-palladation and subsequent $\beta$-hydride elimination [6971]. Double bond regioisomers (between C7 \& C8 or C13 \& C14) were obtained. Oxidation with DDQ yielded the 1,6-unsaturated ketone 72. Selective epoxidation followed by reductive epoxide opening furnished the desired alcohol 73 [72]. Alcoholdirected 1,4-reduction using $\mathrm{LiAlH}_{4}$ [73] followed by ether formation gave methyl ether 74. Reduction of the remaining ketone moiety gave the equatorial alcohol exclusively. Ortholithiation followed by the addition of carbon dioxide [74,75] resulted in the formation of carboxylic acid 75. Birch reduction with concomitant methylation [76,77] followed by selective hydrogenation and reduction of the carboxylic acid resulted in the formation of alcohol 76. Installation of the remaining quarternary carbon center was achieved by the conjugate addition of cyanide [78]. Reduction of the newly introduced nitrile yielded the unexpected stable pentacycle 77. Formation of the missing methyl group (compound 78) could be achieved using forcing Wolff-Kishner-conditions. Benzoate formation and global oxidation [79,80] finally furnished scopadulcic acid B (79). A similar approach was used by the same group in their total synthesis of scopadulcic acid A [81].

Davies and coworkers [82] utilized the DVCPR embedded in a formal [4 +3]-cycloaddition [83] in the total syntheses of the related sesquiterpene metabolites tremulenolide A $\mathbf{( 8 8}$, see Scheme 11) and tremulenediol A (89), isolated from a fungal pathogen [84]. Horner-Wadsworth-Emmons olefination of the starting ketone 80 [85] provided an $E / Z$-mixture of $\alpha, \beta$-unsaturated ester 81. Deprotonation followed by an acidic quench resulted in deconjugation to give $\beta, \gamma$-unsaturated ester $\mathbf{8 2}$. Diazotransfer using $p$-ABSA [86] yielded diazoester 83. Selective rhodium-catalyzed cyclopropanation of the cis-double bond [87,88] of diene $\mathbf{8 4}$ [89] furnished cis-divinylcyclopropane $\mathbf{8 5}$, which underwent DVCPR upon Kugelrohr distillation at $140{ }^{\circ} \mathrm{C}$ to give bicyclic 86. Selective hydrogenation of the less substituted double bond using Wilkinson's catalyst [90] gave $\alpha, \beta$ unsaturated ester 87. Removal of the acetate protecting group with concomitant lactonization concluded the total synthesis of tremulenolide A $(\mathbf{8 8})$, whereas global reduction resulted in the formation of tremulenediol A (89).

Davies and co-worker $[91,92]$ investigated the formal synthesis of the sequiterpene-hydroquinone derivative frondosin B (99, see Scheme 12) [93] via an enantioselective cyclopropanation of trans-piperylene and subsequent divinylcyclopropane rearrangement, to further demonstrate the versatility of their formal [4 +3] cycloaddition [82]. Starting from 4-methoxyphenol (90) Friedel-Crafts acylation and cyclization provided bicycle 91. Wittig olefination furnished benzofuran 92. Diazotransfer using $p$-ABSA yielded the crucial diazo compound $\mathbf{9 3}$, which was used in the following enantioselective cyclopropanation with the lesser substituted double bond of piperylene under $\mathrm{Rh}_{2}(R \text {-DOSP })_{4}$ catalysis. Cis-divinylcyclopropane intermediate 94 underwent in situ DVCPR under the reaction conditions, and rearomatization of the benzofuran moiety provided $\mathbf{9 5}$. Reduc- 


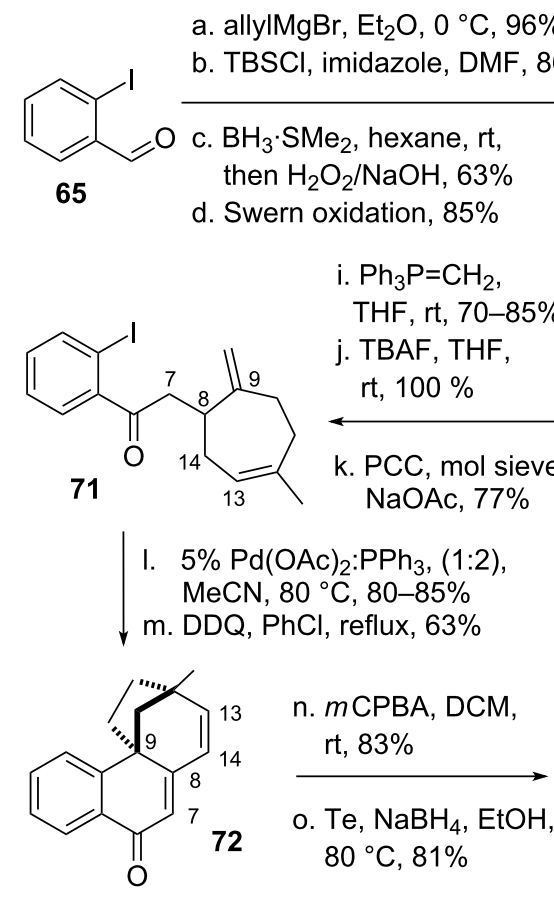

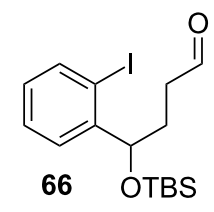

66

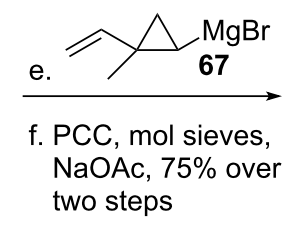

h. benzene,

reflux,

then PPTS,<smiles>CC1=CC(CC([Te])c2ccccc2I)C(=O)CC1</smiles>

70
$\mathrm{EtOH} / \mathrm{H}_{2} \mathrm{O}$

99\% over two steps<smiles>C[C@]1(/C=C/[Sb])C[C@@H]1C(=O)CCC([18OH])c1ccccc1I</smiles>

g. TMSOTf, $\mathrm{NEt}_{3}$, $\mathrm{DCM}, 0^{\circ} \mathrm{C}$<smiles>C[C@]1(C=S)CC1/C([OH+])=C\CC([OH2+])c1ccccc1I</smiles><smiles>CO[C@H]1C[C@H]2CC(=O)c3ccccc3[C@]23CC[C@]1(C)C3</smiles>

q. MeOTf, 2,6-di-tertbutylpyridine, DCM, rt, 75\%

t. $\mathrm{Li}, \mathrm{NH}_{3} / \mathrm{THF}(4: 1)$, reflux; isoprene; Mel

u. $\mathrm{H}_{2}, \mathrm{Rh} / \mathrm{Al}_{2} \mathrm{O}_{3}$

v. $\mathrm{LiAlH}_{4}, \mathrm{THF}, 0^{\circ} \mathrm{C}$

w. $\mathrm{MnO}_{2}, \mathrm{DCM}, \mathrm{rt}$, $55 \%$ over four steps

$$
\begin{array}{|l}
\text { r. } \mathrm{LiAlH}_{4}, \mathrm{THF} \\
-78{ }^{\circ} \mathrm{C} \\
\text { s. } n \text {-BuLi, TMEDA, } \\
\text { pentane, reflux, } \\
\text { then } \mathrm{CO}_{2}, 63 \% \\
\text { over two steps }
\end{array}
$$<smiles>CO[C@H]1C[C@H]2C[C@H](O)c3c(C(=O)O)cccc3[C@@]23CC[C@]1(C)C3</smiles>

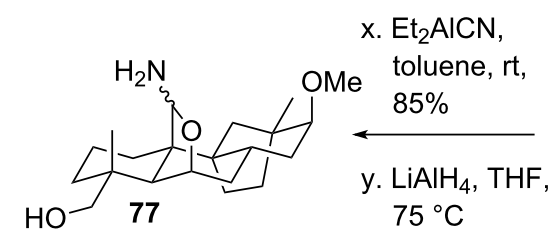

z. $\mathrm{H}_{2} \mathrm{NNH}_{2} \cdot \mathrm{HCl}, \mathrm{H}_{2} \mathrm{NNH}_{2} \cdot \mathrm{H} 2 \mathrm{O}$, ethyleneglycol, $195^{\circ} \mathrm{C}$;

$\mathrm{KOH}, 195^{\circ} \mathrm{C}, 75 \%$ over two steps<smiles>C[C@]1(CO)CCCC[C@]12CC[C@]1(C)C[C@H](O)C3=C2C[C@H]1CC3=O</smiles>

76

aa. TBSOTf, 2,6-lutidine, $-70{ }^{\circ} \mathrm{C}$, BzOTf, 2,6-lutidine, rt, $78 \%$ ab. TBAF, THF, rt, $\mathrm{RuCl}_{3} \cdot \mathrm{H}_{2} \mathrm{O}, \mathrm{NalO}_{4}, \mathrm{MeCN} / \mathrm{CCl}_{4} / \mathrm{H}_{2} \mathrm{O}, 57 \%$

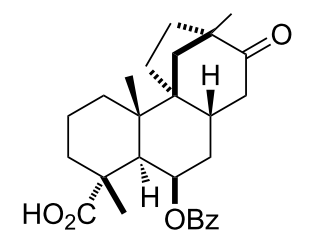

scopadulcic acid B (79)

Scheme 10: Overman's total synthesis of scopadulcic acid B.

tion of the less hindered double bond yielded tricycle 96, for which the yield and enantioselectivity was determined starting from 93. Standard functional group interconversion first provided exo-methylene 97, followed by ruthenium-catalyzed oxidative cleavage of the installed exo-methylene moiety [94] to give tricyclic ketone $\mathbf{9 8}$, which can be converted to frondosin B (99) in three steps according to Danishefsky and co-workers $[95,96]$.
The groups of Davies and Sarpong [97] teamed up for the total syntheses of the diterpenoids barekoxide (106, see Scheme 13) [98] and barekol (107) [99], isolated from the sponges Chelonaplysilla erecta and Raspailia sp. They envisioned a formal $[4+3]$-cycloaddition with an intermediate DVCPR [82]. Starting from diene 100, enantioselective cyclopropanation catalyzed by $\mathrm{Rh}_{2}(R \text {-PTAD })_{4}$ took place using vinyldiazo compound $\mathbf{1 0 1}$ to form cis-dinvinylcyclopropane intermediate $\mathbf{1 0 2}$. 


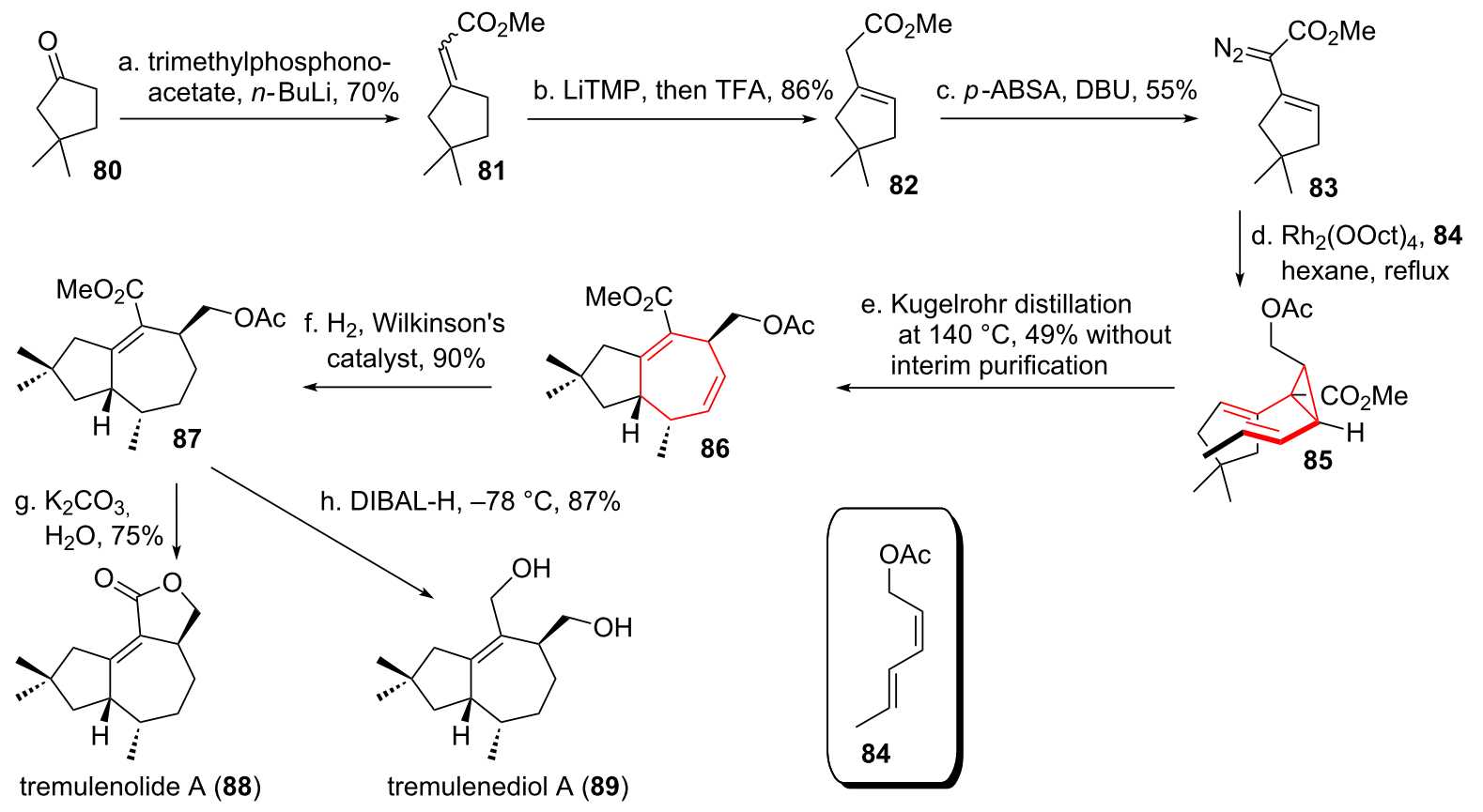

Scheme 11: Davies' total syntheses of tremulenolide A and tremulenediol A.<smiles>C/C=C\[C@H](C)[C@@H](CO)c1coc2cc(OC)ccc12</smiles><smiles>COc1ccc2oc3c(c2c1)C(C)CCCC3C(C)=O</smiles>

g. $\mathrm{LiAlH}_{4}$ h. $\mathrm{TsCl}, \mathrm{NEt}_{3}$

i. DBU, DMF, $130{ }^{\circ} \mathrm{C}, 81 \%$<smiles>C=C1CCCC(C)c2c1oc1ccc(OC)cc21</smiles>

e. $\mathrm{Rh}_{2}(R \text {-DOSP })_{4}$ trans-piperylene, toluene, $-78^{\circ} \mathrm{C}$ to $80^{\circ} \mathrm{C}$<smiles>COc1ccc2occ(C(=N)C(C)=O)c2c1</smiles>

93

j. $\mathrm{RuCl}_{3} \cdot \mathrm{H}_{2} \mathrm{O}$, oxone, $\mathrm{NaHCO}_{3}, \mathrm{MeCN}, \mathrm{H}_{2} \mathrm{O}$, $73 \%$ $57 \%, 97 \%$ ee, $>94 \%$ de

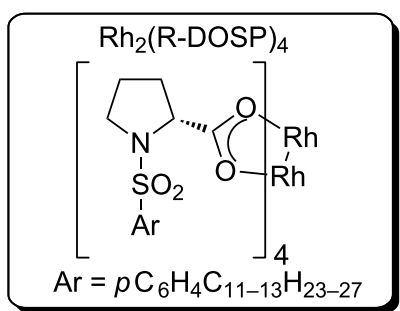<smiles>CC1CCC2=C(CCCC2(C)C)c2c1oc1ccc(O)cc21</smiles>

frondosin B (99)<smiles>C#CC</smiles><smiles>COc1ccc2oc3c(c2c1)C(=O)CCCC3C</smiles> 


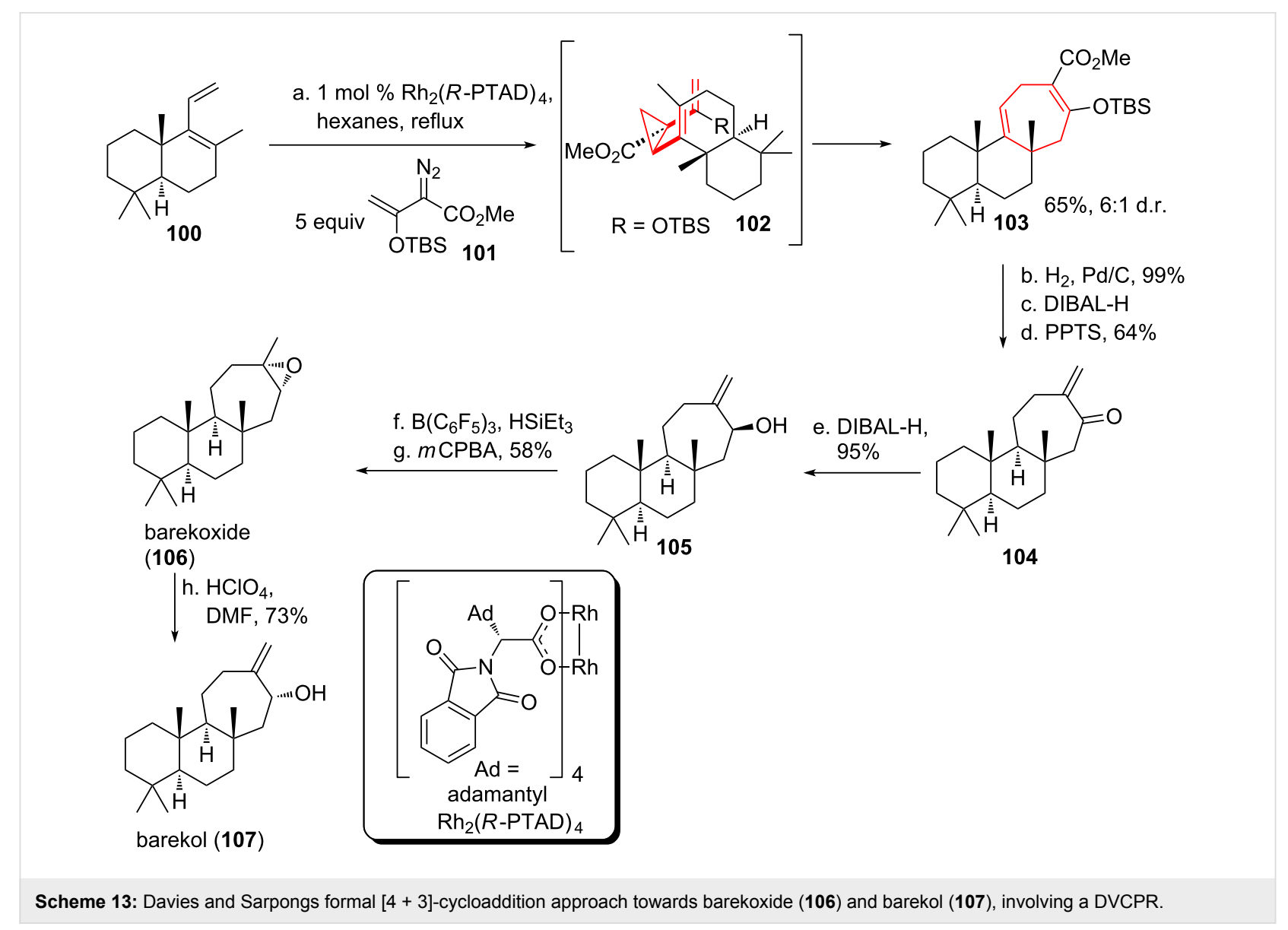

Rearrangement yielded tricycle $\mathbf{1 0 3}$ in both good yield and good diastereomeric ratio. Selective hydrogenation of the more electron rich double bond followed by reduction of the ester furnished $\alpha, \beta$-unsaturated ketone $\mathbf{1 0 4}$ after PPTS-catalyzed elimination of water. Subsequent DIBAL-H reduction yielded the alcohol epimer 105 of barekol (107). Deoxygenation with concomitant isomerization of the double bond according to Gevorgyan [100] was followed by epoxidation to provide barekoxide (106). Acid-catalyzed isomerization finally yielded barekol (107).

Davies and coworkers [101-103] used the formal [4 + 3]-cycloaddition approach to access the diterpene 5-epi-vibsanin $\mathrm{E}$ (115), from the plant Viburnum awabuki (see Scheme 14) [104] Starting from triene 108 cyclopropanation was achieved using vinyldiazo compound $\mathbf{1 0 1}$. The fomal [4 +3$]$-cycloaddition proceeded through cis-divinylcyclopropane $\mathbf{1 0 9}$ to yield rearranged cycloheptadiene 110. Desilylation was achieved using TBAF, followed by formation of a vinyl triflate and Stille coupling with tributyltin hydride. The oxidation state of the remaining ester was adjusted to the corresponding aldehyde, followed by a Lewis acid-catalyzed intramolecular inverse-electron-demand hetero-Diels-Alder reaction to give tricycle $\mathbf{1 1 1}$
The enol ether moiety was reduced using $\mathrm{NaCNBH}_{3}$, followed by allylic Riley oxidation and PCC-mediated enone formation. Copper-catalyzed conjugate addition in the presence of TMSCl [105] yielded silyl enol ether 112. Subsequent introduction of the side chain in $\mathbf{1 1 3}$ via a Claisen rearrangement was followed by MOM-cleavage. Oxidation furnished an intermediate aldehyde, followed by Wacker oxidation and the Anders-Gaßner variant [106-109] of the Wittig reaction to furnish 5-epivibsanin E (115).

Echavarren and coworkers [110] used a DVCPR to target the sesquiterpenoid schisanwilsonene A (126, see Scheme 15), isolated from Schisandra wilsoniana [111], a plant used in traditional chinese medicine. Submission of 1,6-enyne 116 to cationic gold-catalyst 117 led to 5-exo-dig cyclization and intermediate formation of bridged bicycle 119. Subsequent 1,5-acylshift afforded vinylcarbenoid 120, which underwent cyclopropanation with the added olefin 118 to give bicycle 121 in decent yield. Double deprotection followed by selective acetal-protection of the less hindered alcohol and oxidation of the remaining unprotected alcohol moiety led to aldehyde $\mathbf{1 2 2}$. Wittig olefination resulted in the formation of non-isolated cis-divinylcyclopropane 123, which immediately underwent DVCPR to give 


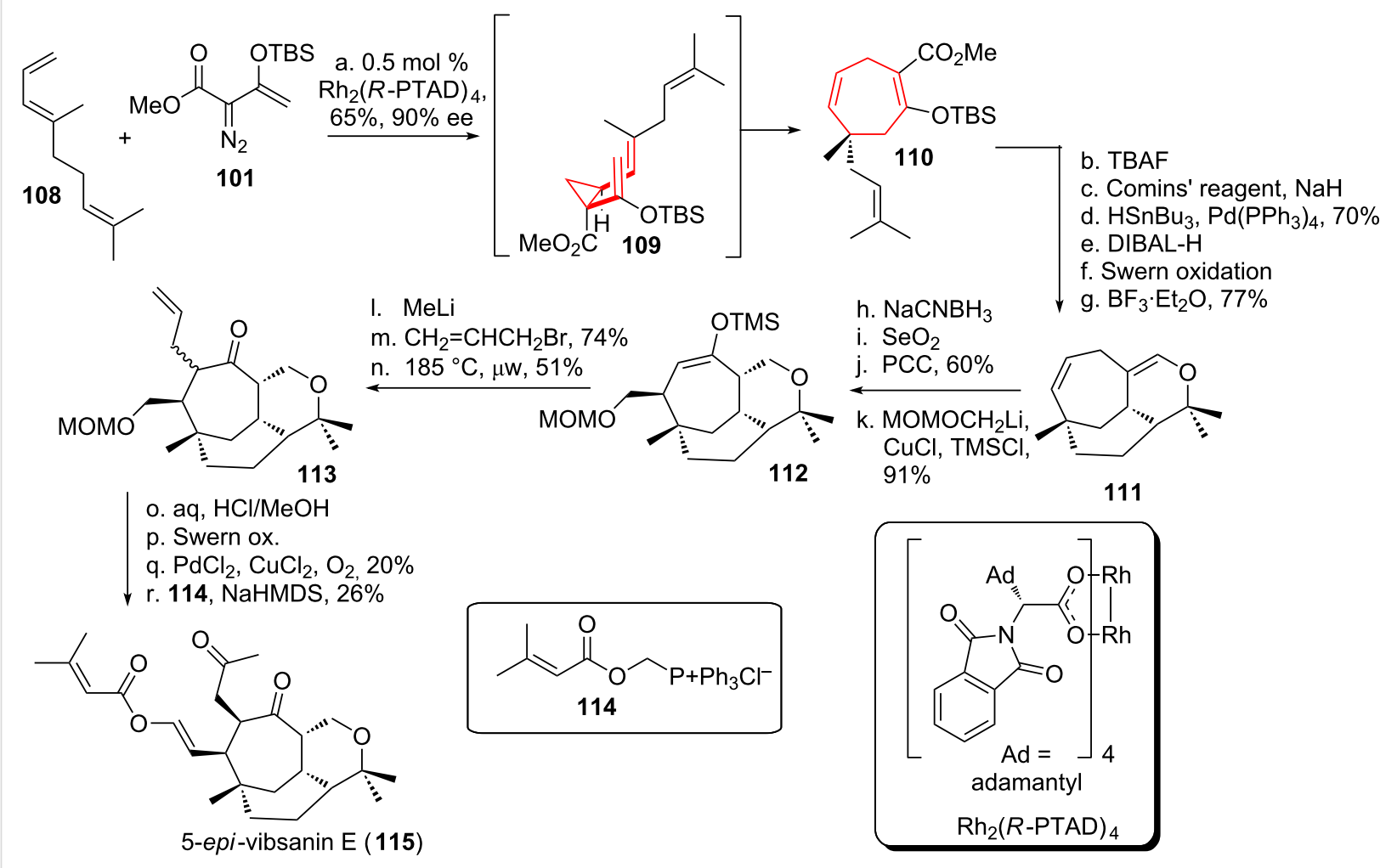

Scheme 14: Davies formal [4 + 3]-cycloaddition approach to 5-epi-vibsanin E (115) containing an intermediate cis-divinylcyclopropane and the corresponding DVCPR.

124 at ambient temperature. Ester 125 was obtained using standard functional group interconversions. The desired natural product schisanwilsonene A (126) was obtained after selective formation of the less hindered $\alpha, \beta$-unsaturated ester and subsequent reduction.

\section{Alkaloid targets}

Davies and co-worker [112] were the first to apply the DVCPR to the total synthesis of alkaloids. Anhydroecgonine methyl ester (131, see Scheme 16) is a tropane alkaloid structurally related to cocaine, which can be detected in the human body after cocaine consumption. It can be degradatively accessed from cocaine through pyrolysis, cocaine congeners can be prepared via conjugate addition afterwards $[113,114]$. Bocprotected pyrrole 127 was subjected to rhodium-catalyzed cyclopropanation with vinyldiazo compound $\mathbf{1 2 8}$ [115,116], bearing a chiral auxiliary [117]. The intermediate cis-divinylcyclopropane 129 rearranged to the corresponding bridged cycloheptadiene $\mathbf{1 3 0}$ in a DVCPR. The chiral auxiliary was removed in the following using methanolysis conditions, followed by reduction of the more electron rich double bond and reductive amination after Boc-deprotection to yield the desired natural product $\mathbf{1 3 1}$ in only five steps.
Perhaps one of the most prominent alkaloid syntheses using a DVCPR was carried out by Fukuyama and coworker [118-120] and targeted gelsemine (146, see Scheme 17 and Scheme 18), an alkaloid with a unique hexacyclic cage structure isolated from Gelsemium Sempervirens [121,122]. Starting from methyl acetoacetate (132), double deprotonation and addition of the more reactive anion to sorbal aldehyde furnished the corresponding alcohol, which was immediately protected as its acetal 133 using ethyl vinyl ether. The necessary diazo moiety was installed using tosylazide as a diazo-transfer reagent to yield 134. Copper catalyzed intramolecular cyclopropanation furnished bicycle 135. Reduction of the carbonyl moiety and protection of the resulting alcohol was followed by ether cleavage and ozonolysis to give aldehyde 136 [123]. Knoevenagel condensation with 4-iodooxindole was achieved in the next step. Pfitzner-Moffatt oxidation [124] followed by elimination furnished trans-divinylcycloproane 137. Submission of this compound to elevated temperature initiated a very smooth DVCPR yielding bicycle 138. The temperature for the predecessing trans-cis divinylcyclopropane isomerization was unusually low. This can be rationalized by the substitution of the divinylcyclopropane with two electron withdrawing groups and the resulting stabilization of the intermediate(s). 


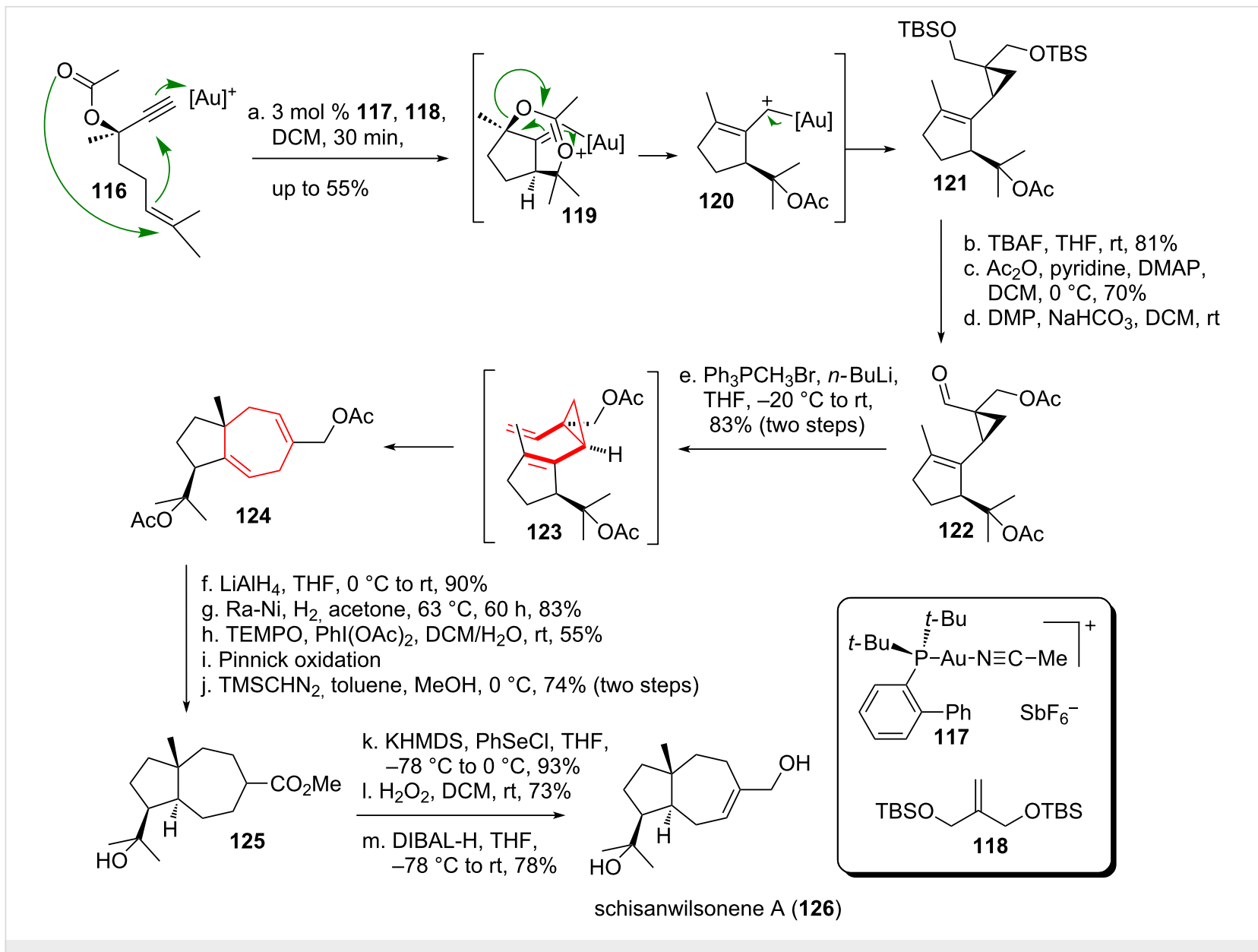

Scheme 15: Echavarren's total synthesis of schisanwilsonene A (126) featuring an impressive gold-catalzed cascade reaction and a DVCPR.

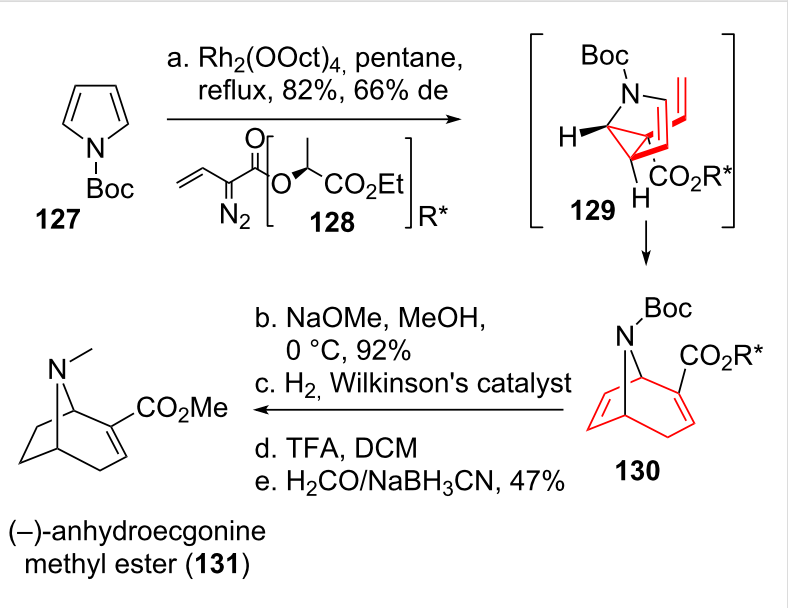

Scheme 16: Davies early example of a formal [4 + 3]-cycloaddition in alkaloids synthesis.

The surplus iodine at the oxindole was crucial for the stereochemical control of the spiro-indolinone system in 138, it was removed in the next step using radical conditions. Horner-Wadsworth-Emmons olefination on the carbonyl moiety followed by protection of the oxindole gave intermediate 139. Conjugate addition of methylamine and protection of the amine was followed by selective reduction of the methyl ester [125]. Protection of the resulting alcohol gave tetracycle 140.

The remaining ester 140 (see Scheme 18) was then converted to the corresponding acid, followed by anhydride formation. Introduction of an acyl azide resulted in a Curtius rearrangement, upon heating the intermediate isocyanate was trapped with EtOH to yield ethyl carbamate protected amine 141. Deprotection of the Alloc-group [126] and chloro carbamate formation furnished 142. Exposure of this compound to a silver source led to the formation of the five-membered lactam, together with an acylimine. This was removed under acidic conditions to furnish aldehyde 143. Tebbe olefination [127] installed the missing double bond in 144. Oxymercuration [128] followed by reductive biphasic demercurization [129] furnished the remaining tetrahydropyran ring, yielding 145. Removal of the MOMprotecting group followed by reduction of the amide concluded Fukuyama's total synthesis of gelsemine (146). 


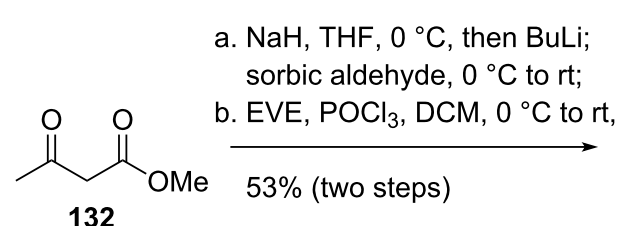

132<smiles>CC=CC=CC(C=[OH+])CC(=O)CC(=O)OC</smiles>

e. $\mathrm{NaBH}_{4}, \mathrm{MeOH}$, $0{ }^{\circ} \mathrm{C}$

f. $\mathrm{Ac}_{2} \mathrm{O}$, pyridine, it<smiles>COC(=O)C1CC(O)CC1C(=O)O</smiles>

136

g. $\mathrm{TsOH}, \mathrm{iPrOH} / \mathrm{H}_{2} \mathrm{O}$,

rt, 74\% (three steps)

h. $\mathrm{O}_{3}, 10 \% \mathrm{MeOH}$, $\mathrm{DCM}$, then $\mathrm{Me}_{2} \mathrm{~S}$,<smiles></smiles>

j. $\mathrm{DCC}, \mathrm{PMSO}$ pyridiniumtrifluoroacetate, rt

k. $\mathrm{NEt}_{3}, \mathrm{DCM}, \mathrm{rt}$, 91\% (two steps)<smiles>CC=CC1CC(C=O)CC(=O)C1C(=O)OC</smiles>

d. cat. $\mathrm{Cu}(\mathrm{acac})_{2}$, $\mathrm{CuSO}_{4}, \mathrm{PhH}$, $85^{\circ} \mathrm{C}, 3 \mathrm{~h}, 68 \%$ $-78{ }^{\circ} \mathrm{C}$ to rt, $89 \%$

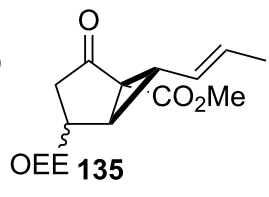

I. $90^{\circ} \mathrm{C}$, toluene/MeCN (1:1), $45 \mathrm{~min}, 98 \%$<smiles>COC(=O)C1=CC2C(=O)C1C13C=CC(I)C(C=C1I)C23</smiles>

138

m. $n-\mathrm{Bu}_{3} \mathrm{SnH}$, cat. AIBN toluene, $95^{\circ} \mathrm{C}, 1 \mathrm{~h}$, $85 \%$

n. $(\mathrm{EtO})_{2} \mathrm{POCH}_{2} \mathrm{CO}_{2} t-\mathrm{Bu}$, BuLi, THF, $65^{\circ} \mathrm{C}$, then $\mathrm{MOMCl}, t$-BuOK, $\mathrm{rt}, 70 \%$

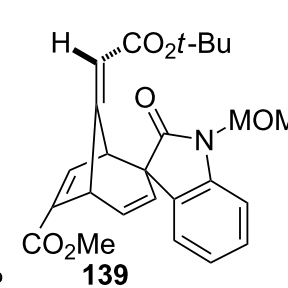

o. $\mathrm{MeNH}_{2}, \mathrm{MeOH}$, rt, quant.

p. Alloc-Cl, pyridine, DMAP, DCM, $0^{\circ} \mathrm{C}$

q. $\mathrm{LiBH}_{4}$, cat. $\mathrm{LiBEt}_{3} \mathrm{H}$, THF, rt

r. $\mathrm{Ac}_{2} \mathrm{O}$, pyridine, $73 \%$ (three steps)

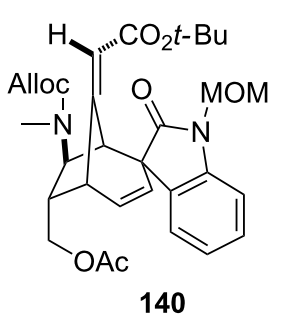

Scheme 17: Fukuyama's total synthesis of gelsemine, part 1.

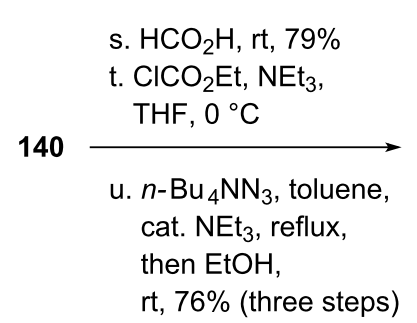

aa. $\mathrm{Hg}(\mathrm{OTf})_{2} \mathrm{PhNMe}_{2}$, $\mathrm{MeNO}_{2}, \mathrm{rt}, 1 \mathrm{~h}$, then satd. $\mathrm{NaCl}$

ab. $\mathrm{NaBH}_{4}, 10 \%$ aq $\mathrm{NaOH}$, $\mathrm{BnEt}_{3} \mathrm{NCl}, \mathrm{DCM}$, rt, $63 \%$ (two steps)

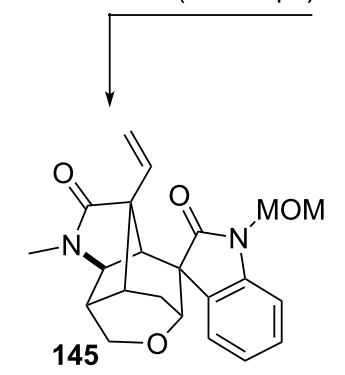

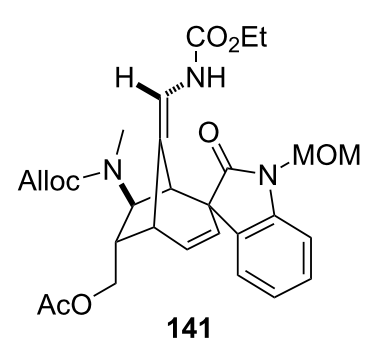

141
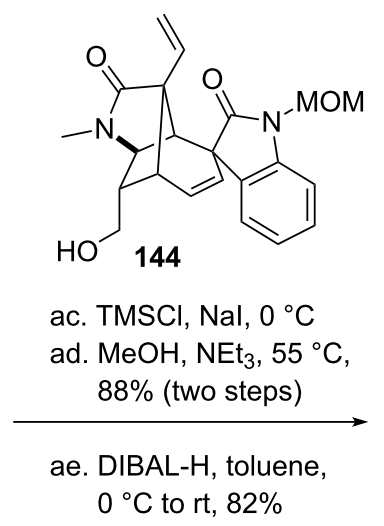

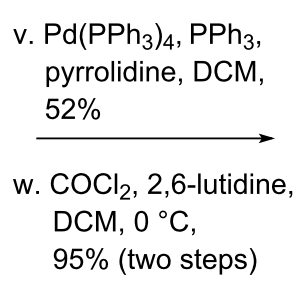

$\mathrm{DCM}, 0{ }^{\circ} \mathrm{C}$,

95\% (two steps)

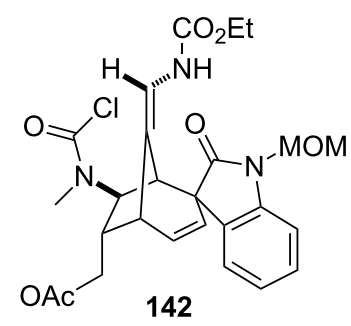

142

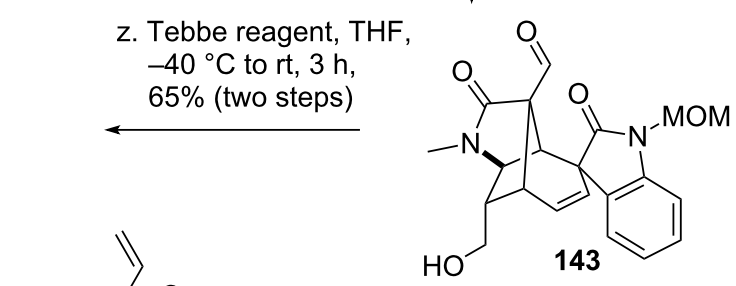

x. AgOTf, $\mathrm{Ag}_{2} \mathrm{CO}_{3}$, DCM, $45^{\circ} \mathrm{C}, 52 \%$ y. $3 \mathrm{~N} \mathrm{HCl}, \mathrm{THF}, \mathrm{rt}$

Scheme 18: Fukuyama's total synthesis of gelsemine, featuring a divinylcyclopropane rearrangement, part 2. 
An approach similar to Davies formal [4+3]-cycloaddition [81] was used by the group of Kende [130] to access the alkaloid isostemofoline (158, see Scheme 19) [131]. Rhodiumcatalyzed cyclopropanation of silyl-enol-diazo compound $\mathbf{1 0 1}$ and Boc-protected pyrrole 147 resulted in the formation of intermediate cis-divinylcyclopropane $\mathbf{1 4 8}$, that rearranged under the reaction conditions to give the corresponding highly substituted bridged cycloheptadiene 149. Deprotection of the enolate, reduction of the remaining double bond and subsequent Krapcho decarboxylation [132] resulted in less functionalized ketone 150. Aldol condensation with furfural followed by $O$-allylation and Claisen rearrangement furnished enone $\mathbf{1 5 1}$. Standard functional group interconversiones were used to access TIPS-protected alcohol 152. Addition of methyllithium at low temperature [133] resulted in stereoselective conjugate attachment of the required methyl group. Deprotection of the alcohol and transformation into a suitable leaving group yielded tosylate 153. Next, the furan was cleaved oxidatively, the resulting acid was converted to the corresponding anhydride, which could be reduced to the alcohol using $\mathrm{NaBH}_{4}$, followed by reoxidation with DMP to yield aldehyde 154. Attachment of furanone enolate 155 [134,135], followed by reoxidation yielded tricycle 156. Deprotection of the amine and the MOMprotected alcohol led to a rearrangement cascade, which smoothly yielded hexacycle $\mathbf{1 5 7}$. This compound could be converted into isostemofoline (158), albeit in low yield. Isostemofoline could not be interconverted into stemofoline (159) using trifluoroacetic acid [136].

Danishefsky and coworkers [137-139] applied the DVCPR in their total synthesis of gelsemine (146, see Scheme 20 and Scheme 21). Starting from bicycle 160 [140] epoxidation using $m$ CPBA furnished epoxide 161 [141,142], which could be converted into vinylcyclopropanecarbaldehyde 162 upon

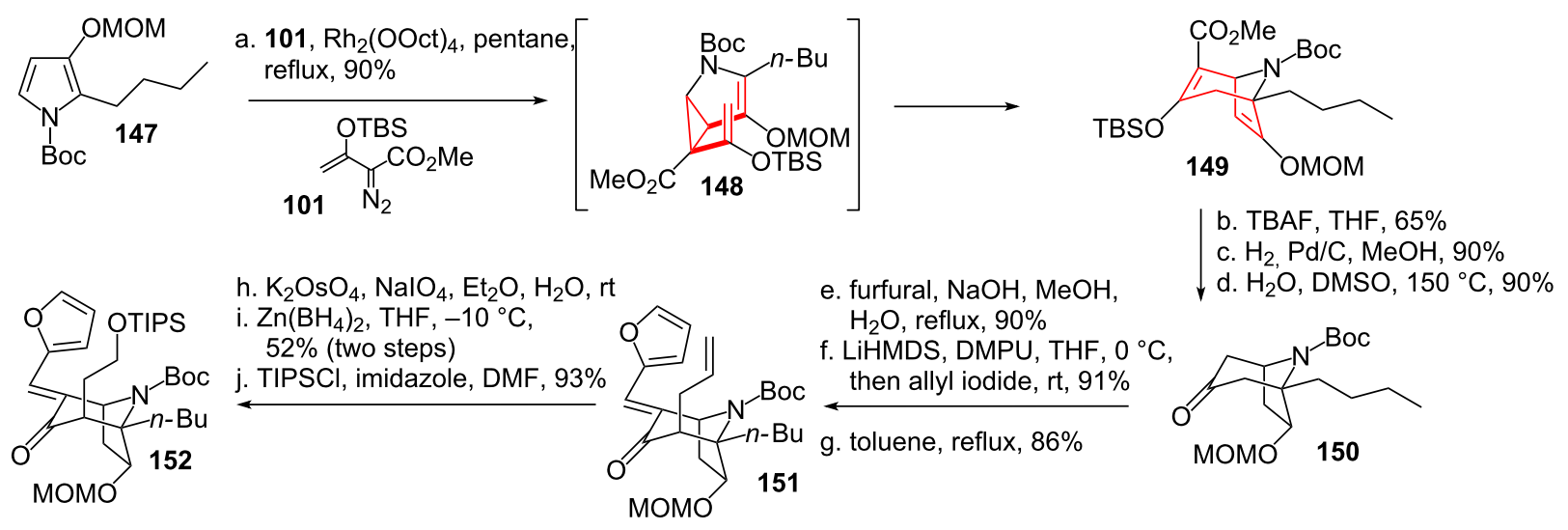

k. 2.2 equiv MeLi, DMPU, $\mathrm{Et}_{2} \mathrm{O},-40^{\circ} \mathrm{C}, 85 \%$

I. TBAF, THF, $90 \%$,

$\checkmark$ m. TsCl, pyridine, $\mathrm{CHCl}_{3}, 90 \%$
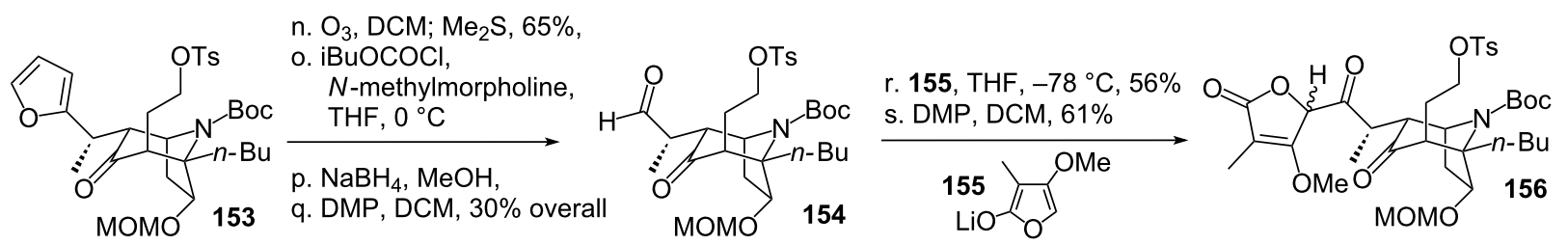

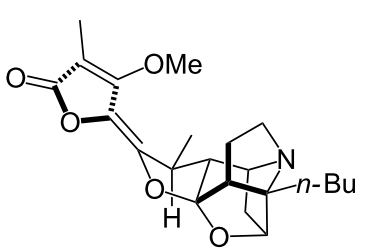

stemofoline (159)

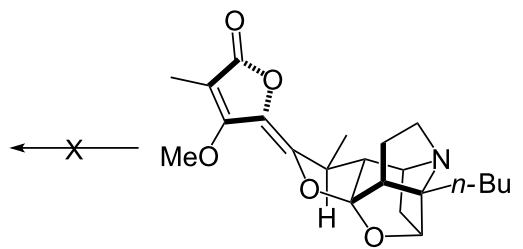

isostemofoline (158) 


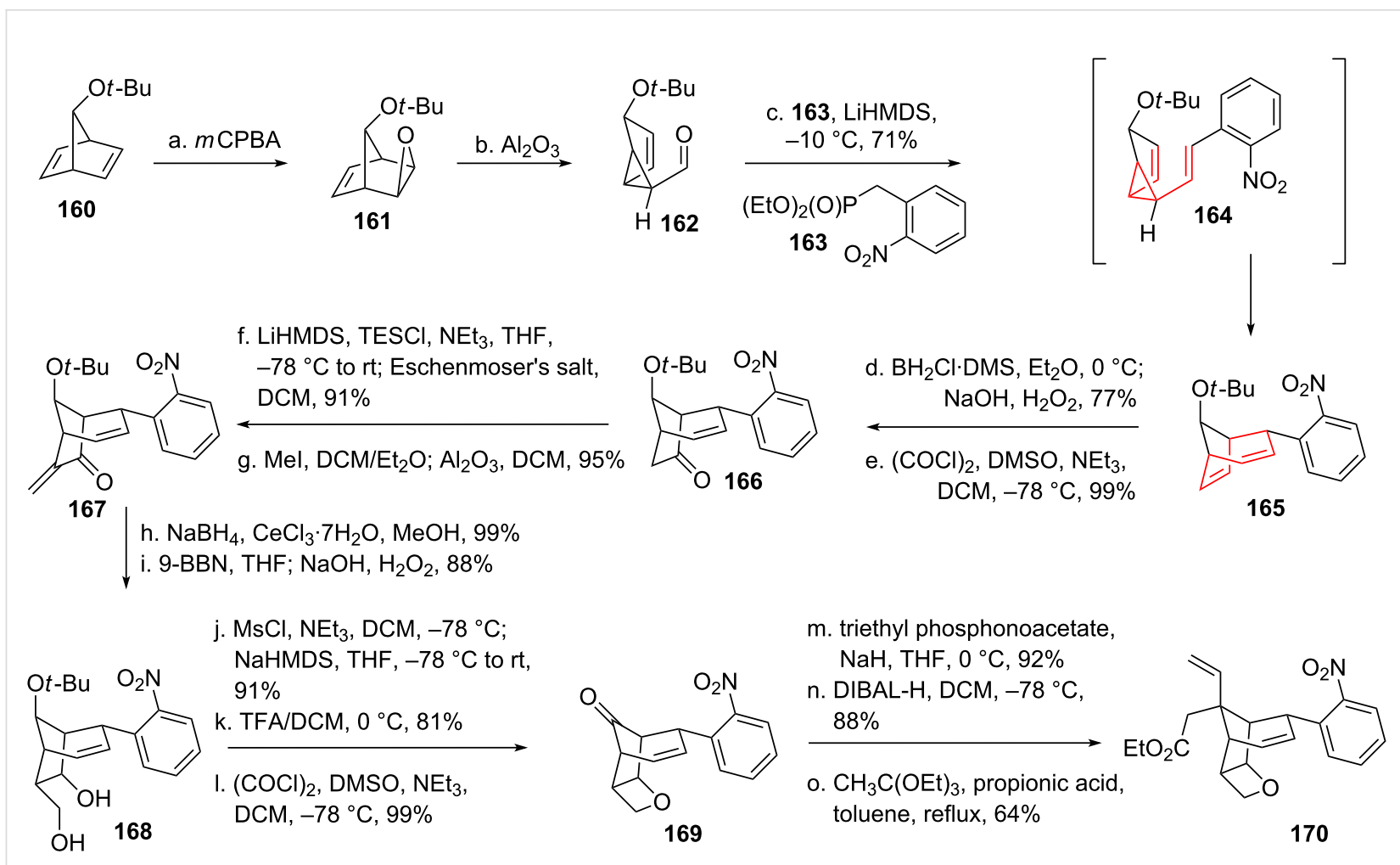

Scheme 20: Danishefsky's total synthesis of gelsemine, part 1.

rearrangement. Olefination using HWE-reagent 163 yielded intermediate cis-divinylcyclopropane 164, which underwent the desired rearrangement at remarkably low temperature to yield bicycle 165. Selective hydroboration/oxidation (directed through participation of the untouched double bond) followed by Swern oxidation gave ketone 166. The enone system 167 was prepared through addition of Eschenmoser's salt, followed by Hoffman elimination of the resulting amine. Luche reduction [143] from the less hindered side followed by hydroboration/oxidation gave diol 168. Mono-mesylation of the primary alcohol followed by the addition of base furnished the signature oxetane moiety. Ether cleavage [144] and Swern oxidation resulted in the formation of ketone $\mathbf{1 6 9}$. HWE-olefination followed by reduction to the allyl alcohol led to allylic ester $\mathbf{1 7 0}$ after a Johnson-Claisen rearrangement [145] upon treatment with triethyl orthoacetate.

Ester 170 was saponificated (see Scheme 21), followed by the formation of an acid-azide. Shiori version [146,147] of the Curtius rearrangement with concomitant addition of $\mathrm{MeOH}$ to the intermediate isocyanate afforded carbamate 171. Oxetane 171 was then opened under Lewis-acidic conditions. The deprotected alcohol was protected to give pentacycle 172. Reduction of the nitro group was followed by Cbz-protection. Allylic alcohol 173 resulted from radical allylic bromination followed by displacement of bromine through water under silver-catalysis. Eschenmoser-Claisen rearrangement [148] led to the formation of the remaining quarternary carbon center, the resulting amide cyclized during the purification on silica to give amide 174. Reduction of this amide to the aminal was followed by dehydration and Lemieux-Johnson [149] oxidative cleavage to give dialdehyde $\mathbf{1 7 5}$. The liberated alcohol moiety was reprotected, followed by cleavage of the amide under basic conditions. Cyclization and Ley-Griffith oxidation [150] took place, followed by deprotection of the alcohol to give spiro-oxindole 176. The formation of the remaining tetrahydropyran was much in line with Fukuyama's synthesis, utilizing the same oxymercuration/reductive demercurization [128,129] sequence (through intermediate 177) yielding 178. The oxindole protecting group was then removed, followed by reduction of the carbamate to the remaining missing methyl group [151] to finish gelsemine (146).

The total synthesis of the monoterpenoid-indole alkaloid gelsemoxonine (197, see Scheme 22) [152], isolated from the leaves of Gelsemium elegans was accomplished by Fukuyama and coworkers $[153,154]$. Starting from furfuryl alcohol (179) an epoxide initiated Achmatowicz reaction [155] took place to give $\alpha, \beta$-unsaturated pyrane 180. Next in line was an enzyme catalyzed dynamic kinetic resolution [156], albeit with unsatis- 

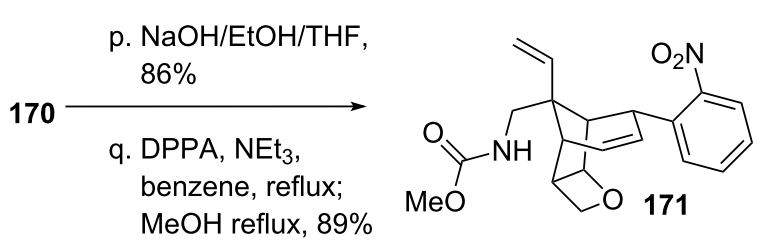

r. $\mathrm{BH}_{3} \cdot \mathrm{Et}_{2} \mathrm{O}, \mathrm{DCM}$

$-78{ }^{\circ} \mathrm{C}$ to $12{ }^{\circ} \mathrm{C}, 64 \%$

s. PivCl, $\mathrm{NEt}_{3}, \mathrm{DMAP}$, DCM, $0{ }^{\circ} \mathrm{C}$ to $\mathrm{rt}, 92 \%$

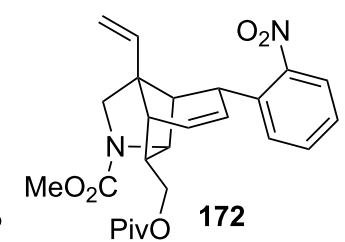

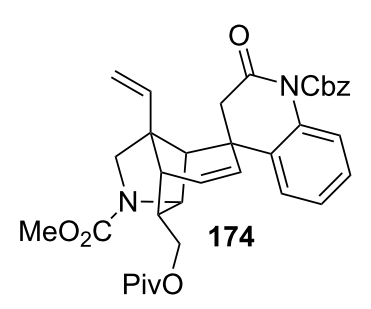

x. $\mathrm{CH}_{3} \mathrm{C}(\mathrm{OMe})_{2} \mathrm{NMe}_{2}$, $m$-xylene, $45 \%$

\section{cyclization on silica \\ $\longleftarrow$}

$\mathrm{MeO}_{2}$

y. DIBAL-H, DCM,

$-78{ }^{\circ} \mathrm{C}, 86 \%$

z. $\mathrm{TsOH} \cdot \mathrm{H}_{2} \mathrm{O}, \mathrm{DCM}$, reflux, $72 \%$

aa. $\mathrm{OsO}_{4}, \mathrm{THF},-25{ }^{\circ} \mathrm{C}$, $\mathrm{NaHSO}_{3}$ (aq), $44 \%$

ab. $\mathrm{NalO}_{4}, \mathrm{THF} / \mathrm{H}_{2} \mathrm{O}$, $99 \%$

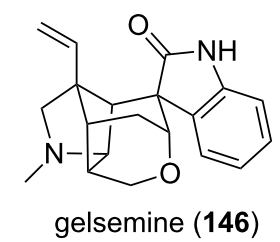

ak. $10 \% \mathrm{NaOH}, \mathrm{THF}$, $67 \%$ (two steps) al. $\mathrm{LiAlH}_{4}, 0{ }^{\circ} \mathrm{C}$ to rt, $81 \%$

$\mathrm{MeO}_{2} \mathrm{C}$
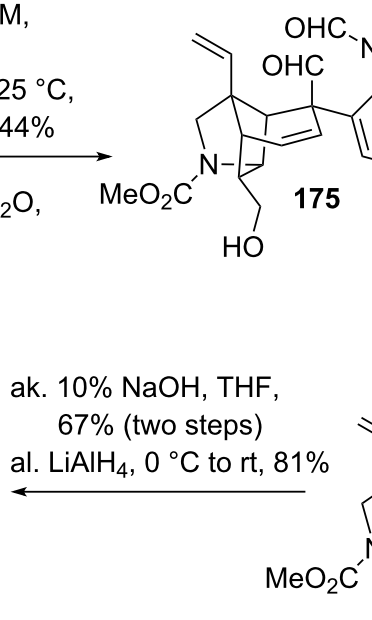

t. zinc dust, THF/HOAc

u. $\mathrm{CbzCl}, \mathrm{NaHCO}_{3}, \mathrm{DCM}$, 94\% (two steps)

v. NBS, AIBN hv, $\mathrm{CCl}_{4}$, DCM, $55-60{ }^{\circ} \mathrm{C}, 60 \%$ brsm

w. $\mathrm{Ag}_{2} \mathrm{O}, \mathrm{CF}_{3} \mathrm{CH}_{2} \mathrm{OH} / \mathrm{H}_{2} \mathrm{O}, 65 \%$

\section{PivO}

ac. TESOTf, $\mathrm{NEt}_{3}, \mathrm{DCM}$, $0{ }^{\circ} \mathrm{C}, 52 \%$

ad. $\mathrm{K}_{2} \mathrm{CO}_{3}, \mathrm{MeOH}$

ae. TPAP, NMO, DCM, molsieves, $78 \%$

af. $\mathrm{HF} \cdot \mathrm{Py}, \mathrm{THF}, 0{ }^{\circ} \mathrm{C}, 99 \% \mathrm{MeO}_{2} \mathrm{C}^{\prime}$

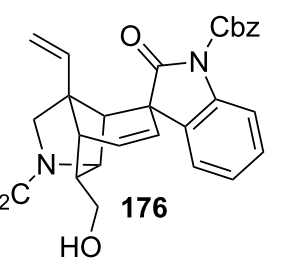

ag. $\mathrm{Hg}(\mathrm{OTf})_{2}$ $\mathrm{MeNO}_{2}$, then sat. $\mathrm{NaCl}, 92 \%$
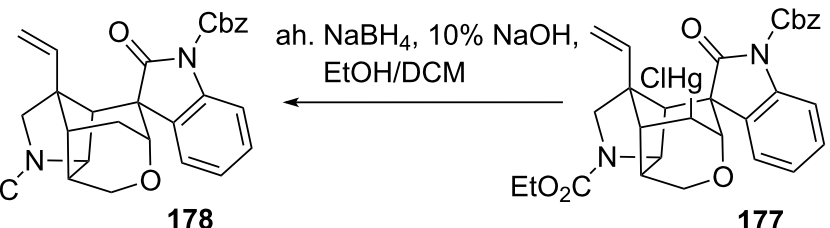

Scheme 21: Danishefsky's total synthesis of gelsemine, part 2.

factory enantiomeric excess. The undesired enantiomer was then selectively cleaved using another enzyme with reversed selectivity to give enantiopure pyranone 181. Cyclopropanation was achieved using a Michael addition initiated ring closure yielding diester 183. Complete reduction furnished triol 184, followed by mono-protection of the least hindered alcohol. The remaining alcohol moieties were then oxidized to the corresponding keto-aldehyde 185. A two-step procedure was employed to generate $\alpha, \beta$-unsaturated oxindole- $N$-methoxide 187 [157,158]. Formation of silyl enol ether 188 furnished the desired cis-divinylcyclopropane, which underwent smooth DVCPR under mild conditions to give bridged bicycle 189. The alcohol was deprotected and oxidized to aldehyde 190. The aldehyde was transferred into the corresponding cyanohydrin trimethylsilyl ether using TMSCN [159-161], followed by protonation of the TMS-enolate and esterification of the intermediate acyl cyanide yielding allyl ester 191. This ester was transferred into the corresponding carboxylic acid, followed by formation of the acid chloride. The chloride was displaced with an azide, which underwent Curtius rearrangement upon heating. The intermediate isocyanate was intercepted by benzyl alcohol to provide secondary Cbz-protected amine 192. Bredereck's reagent (193) [162] was used to generate enamine 194. The enol-form of the remaining carbonyl moiety was transformed into the corresponding vinyl chloride using Vielsmeier's reagent $[163,164]$. Dechlorination $[165,166]$ was then achieved and yielded $\alpha, \beta$-unsaturated aldehyde 195 upon hydrolysis. Grignard addition to the newly formed aldehyde followed by reoxidation furnished the side chain of compound 196. Treatment of unsaturated ketone 196 with Triton B and TBHP 


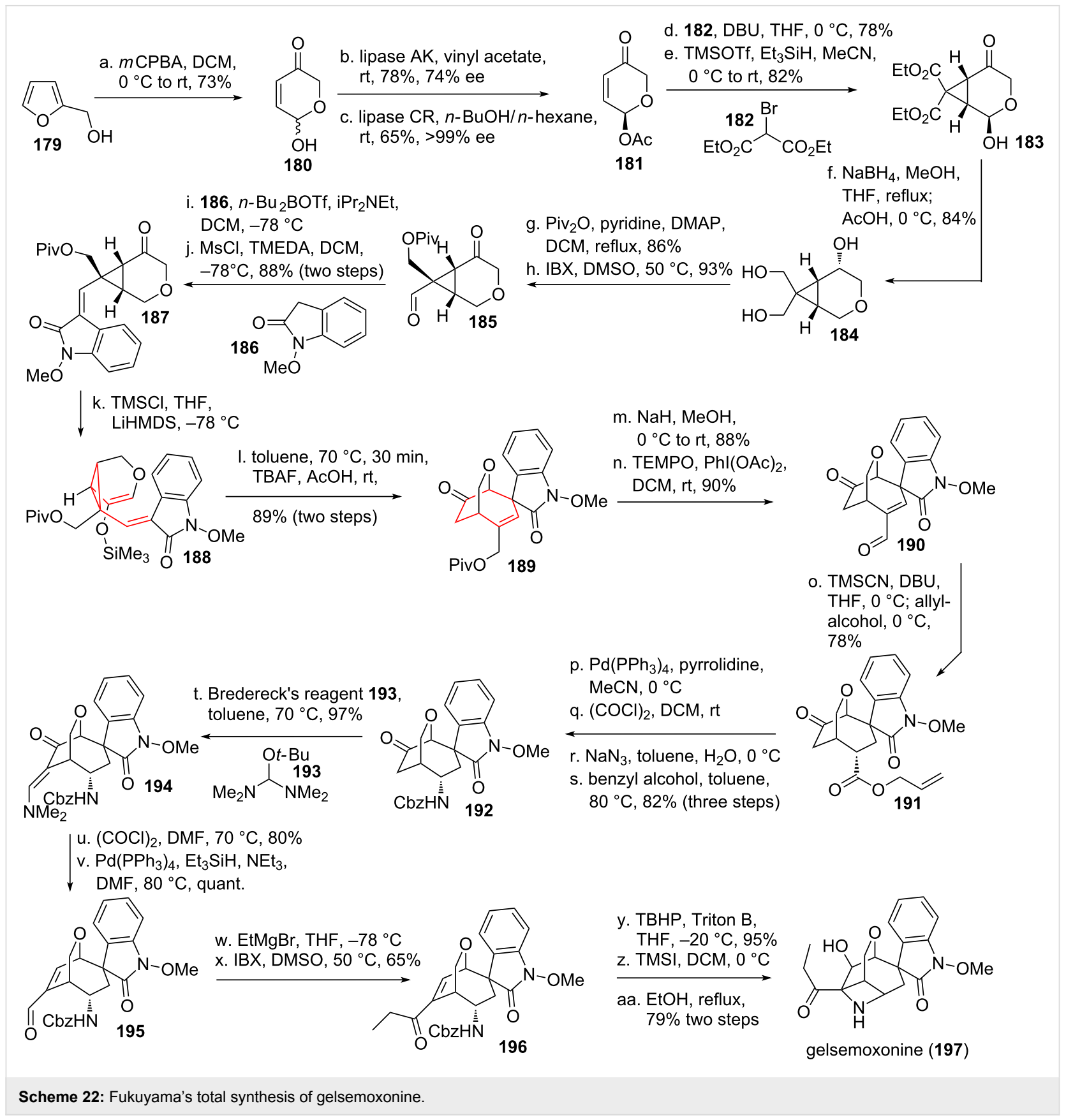

yielded the epoxide resulting from top-face attack. The surplus Cbz-group was then deprotected using TMSI $[167,168]$. The final azetidine formation took place upon refluxing in ethanol to give gelsemoxonine (197).

\section{Further synthetic applications}

The group of Wender applied the DVCPR in an approach towards the core skeleton of tiglianes (like phorbol 206, see Scheme 23), daphnanes and ingenanes [169] in 1980 [170]. Starting from $\alpha$-bromoenone 198 a Corey-Chaykovsky cyclopropanation reaction was achieved to yield cyclopropane 199.
The keto-group was removed using a three step sequence, with concomitant reduction of the ester to give alcohol 200. Oxidation and Wittig olefination gave olefin 201. Lithium bromide exchange followed by 1,2-addition to ketone $\mathbf{2 0 2}$ yielded tricyclic 203, which was immediately subjected to acidic hydrolysis to give the desired tricyclic core skeleton 205 in 51\% yield through transition state 204 .

The group of Davies [171] demonstrated the impressive synthetic power of the DVCPR in their core structure synthesis of CP-263,114 (212, see Scheme 24) [172,173]. Subjection of 


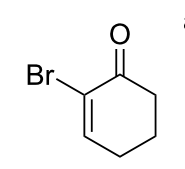

198 a. $\mathrm{Me}_{2} \mathrm{SCHCO}_{2} \mathrm{Et}$, benzene, $80^{\circ} \mathrm{C}$,

$23 \mathrm{~h}, 84 \%$ E<smiles>CCOC(=O)C1C2(Br)CCCC(=O)C12C(=O)OCC</smiles>

b. $\mathrm{NaBH}_{4}, \mathrm{MeOH},-10^{\circ} \mathrm{C}$ c. $\mathrm{MsCl}, \mathrm{NEt}_{3}, \mathrm{Et}_{2} \mathrm{O}, 0^{\circ} \mathrm{C}$

d. $\mathrm{LiAlH}_{4}, 0^{\circ} \mathrm{C}, 10 \mathrm{~min}, 61 \%$

199<smiles>OC[C@H]1C[C@H]2CCCC[C@H]12</smiles>

200 DCM, $69 \%$ f. $\mathrm{Ph}_{3} \mathrm{P}=\mathrm{CH}_{2}$, cyclohexane, benzene, rt,

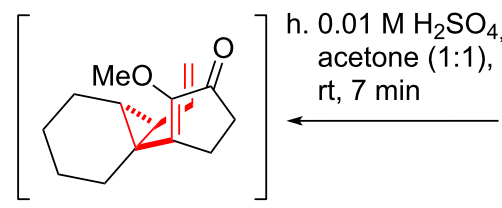

204

$51 \%$ from 201

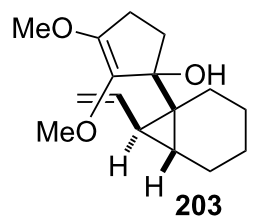

g. $t$-BuLi, $\mathrm{Et}_{2} \mathrm{O}$ $-78^{\circ} \mathrm{C}$ to $0^{\circ} \mathrm{C}$ then 202

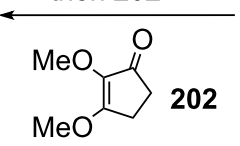

202<smiles>COC12CC=CC3CCCCC3=C1CCC2=O</smiles>

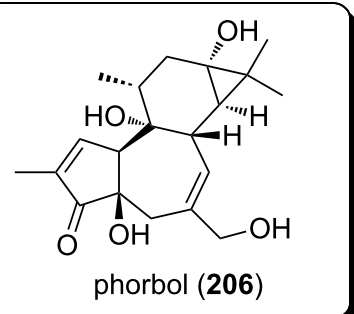<smiles>C=C[C@H]1C(Br)CCCC[C@@H]1[OH2+]</smiles>

Scheme 23: Wender's synthetic access to the core skeleton of tiglianes, daphnanes and ingenanes.

diazofuran $\mathbf{2 0 7}$ to rhodium catalysis resulted in the formation of 209, 210 and 211 in solvent-dependent ratios. The sole product arising from the desired DVCPR via $\mathbf{2 0 8 "}$ is the major product 210. The two remaining products arise from trans-silylation and fragmentation (208' to 209) or via ionic intermediate $\mathbf{2 0 8}$ "' and fragmentation to give 211. The different product distribution can be controlled by the choice of the solvent. Notably cycloheptadiene $\mathbf{2 1 0}$ arising from the DVCPR contains two as well as the related trans-silylated compound 209. This demonstrates the huge driving force of the DVCPR, as two highly strained olefins are favoured over a cyclopropane-moiety.

Wood and coworkers [174] applied the DVCPR in the core structure synthesis of actinophyllic acid (218, see Scheme 25) [175]. Subjection of diazo compound 213 to copper catalysis yielded vinylcyclopropane 214. Deprotonation and silyl ether

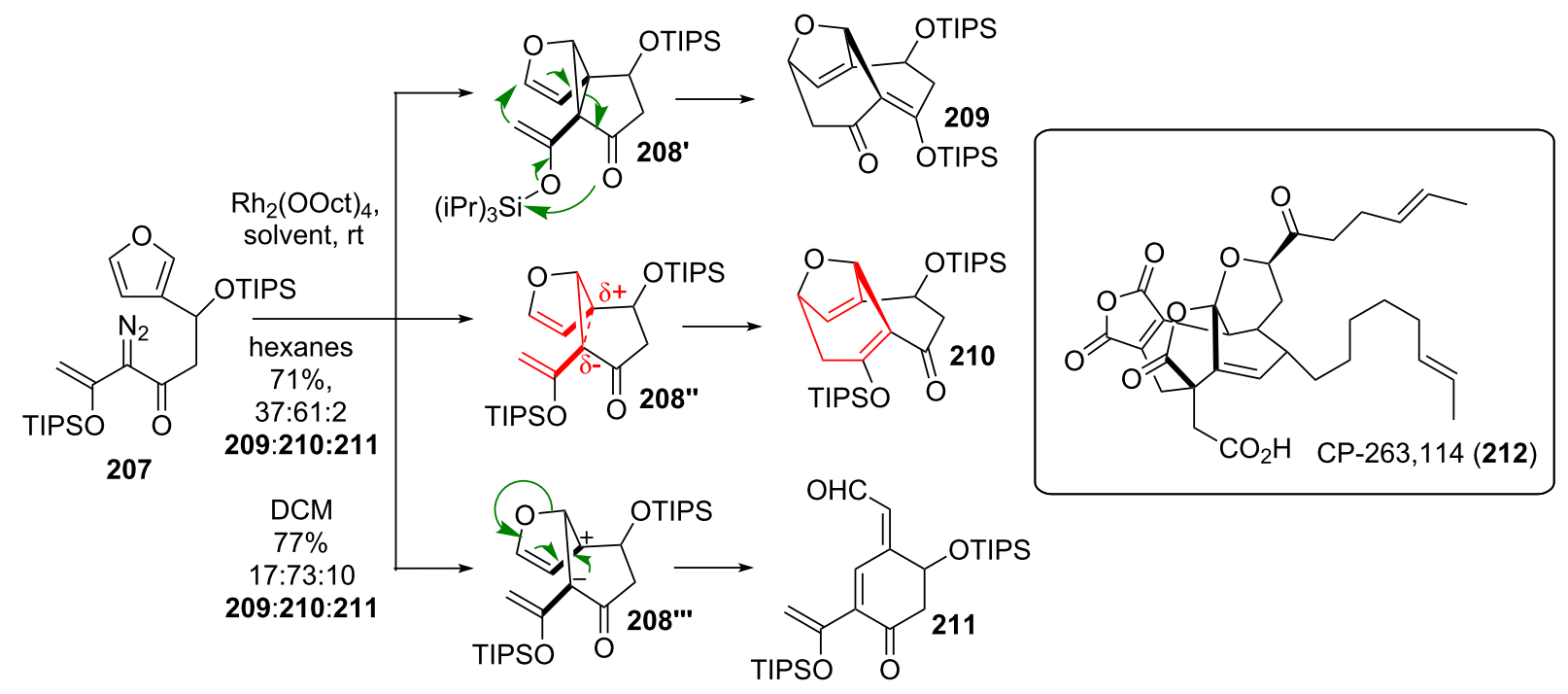

Scheme 24: Davies' approach towards the core skeleton of CP-263,114 (212). 

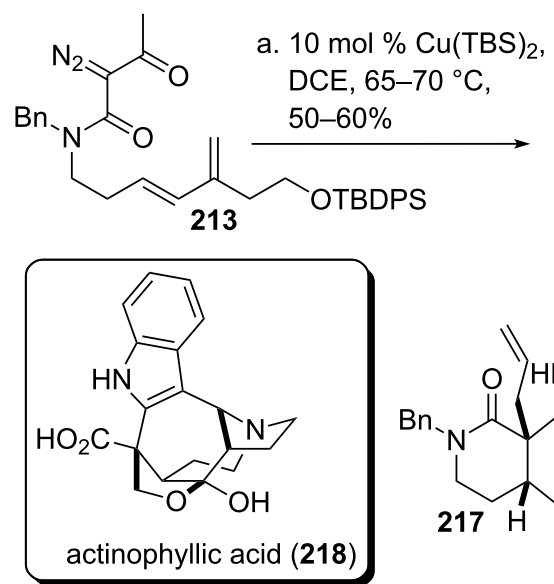

$217 \mathrm{H}$

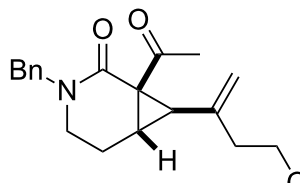

214

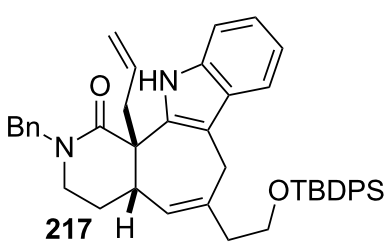

b. TBSOTf, $\mathrm{NEt}_{3}, \mathrm{DCM}$

$-40^{\circ} \mathrm{C}$ to $\mathrm{rt}$,

then $0.1 \mathrm{~N} \mathrm{HCl}, 73 \%$

OTBDPS

c. $10 \mathrm{~mol} \% \mathrm{Pd}\left(\mathrm{PPh}_{3}\right)_{4}$, $\mathrm{MeOCO}_{2}$ allyl (excess),

THF, rt, $91 \%$

d. $10 \mathrm{~mol} \% \mathrm{Sc}(\mathrm{OTf})_{3}$, $\mathrm{PhNHNH}_{2}, \mathrm{DCM}$, rt

e. $\mathrm{ZnCl}_{2}$, toluene, $165^{\circ} \mathrm{C}, \mu \mathrm{w}, 64 \%$
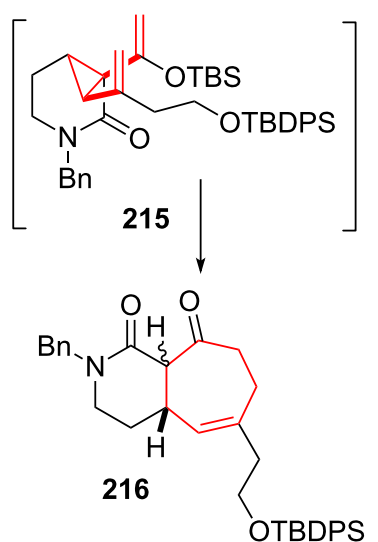

Scheme 25: Wood's approach towards actinophyllic acid.

formation resulted in intermediate cis-divinylcyclopropane $\mathbf{2 1 5}$, which smoothly underwent DVCPR to give cyclohexane $\mathbf{2 1 6}$. Tsuji-Trost allylation [176,177] furnished the quartenary carbon center. A two-step Fischer-indole strategy [178,179] finished tetracycle 217 under forcing conditions.

Takeda and coworkers [180] set out to investigate the use of an anionic oxy-cis-divinylcyclopropane rearrangement to build up the diterpenoid cyanthin skeleton [181-183] like that of allocyathin $B_{2}$ (226, see Scheme 26), which was isolated from bird's nest fungi [184-189]. Starting from $\alpha, \beta$-unsaturated ketone 219 addition of ethynylmagnesium bromide took place, followed by a Rupe rearrangement [190] using refluxing acetic acid as solvent to give ketone 220. Addition of deprotonated ketone 220 onto acryloylsilane 221 [191] gave alkoxy intermediate 222, which underwent a Brook rearrangement followed by cyclopropane formation to yield anionic $\mathbf{2 2 3}$ in situ [192]. The aforementioned anionic oxy-cis-divinylcyclopropane rearrangement took place, yielding tricycle 224. DIBAL-H reduction gave the corresponding alcohol stereoselectivly, followed by removal of the TMS-group at C10 with NBS and further enone formation upon treatment with TBAF to give tricyclic core skeleton 225 [192]. This reaction sequence constitutes a very nice example of a formal [4+3]-cycloaddition, without the use of a transition metal catalyst.

Donaldson and coworkers [193] used the DVCPR en route towards the core skeleton of the sesquiterpenoid guianolide family [194,195]. Starting from readily prepared vinyl bromide 227 (see Scheme 27) formation of the corresponding Grignard species was acomplished, followed by addition to organoiron complex 228 to give (pentenediyl)iron complex 229. Oxidation led to the formation of the desired divinylcyclopropane, followed by reduction of the ester to the desired alcohol to give
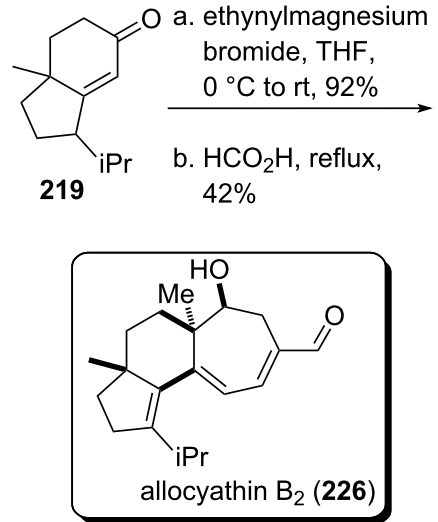
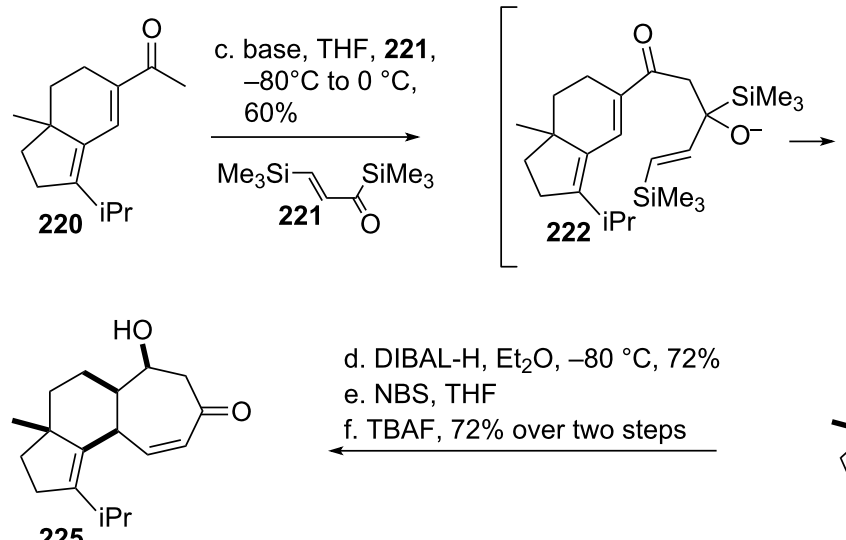

d. DIBAL-H, $\mathrm{Et}_{2} \mathrm{O},-80^{\circ} \mathrm{C}, 72 \%$

e. NBS, THF

f. TBAF, $72 \%$ over two steps
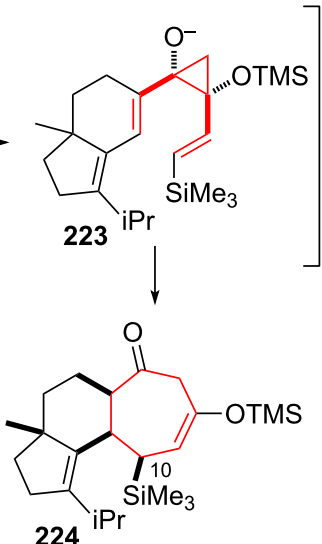

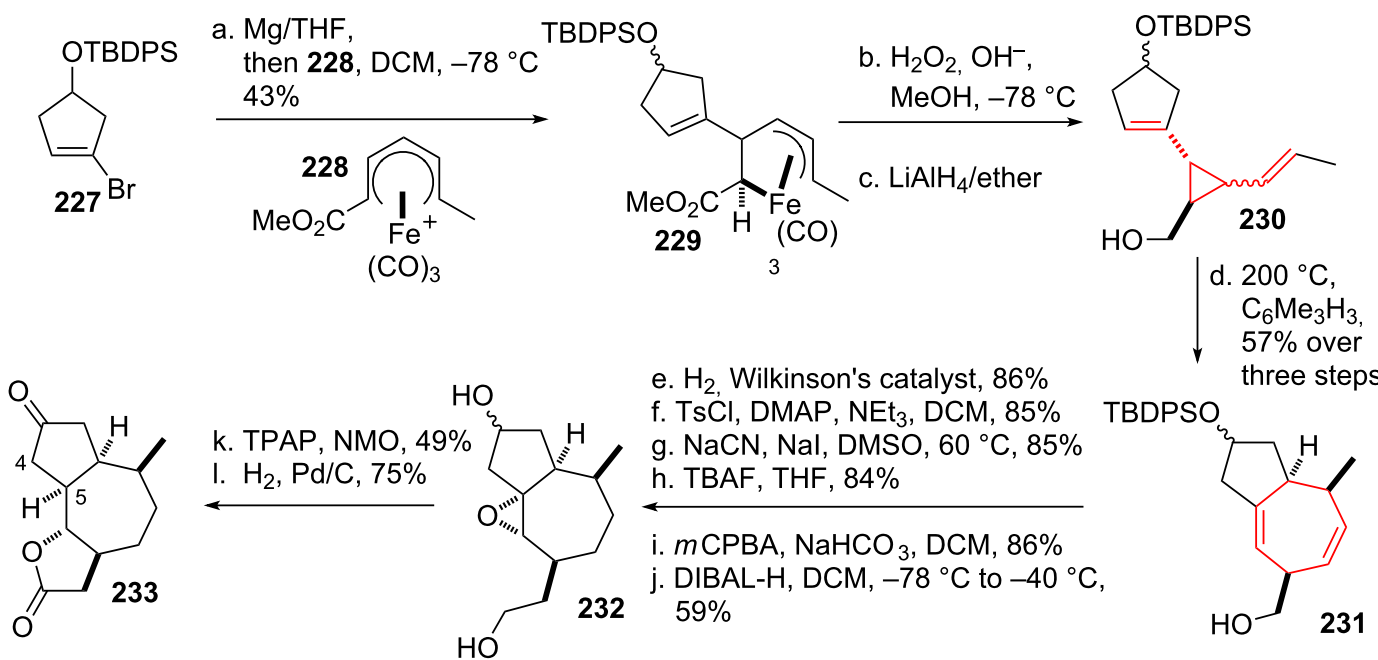

e. $\mathrm{H}_{2}$, Wilkinson's catalyst, $86 \%$

f. TsCl, DMAP, NEt 3 , DCM, $85 \%$

g. NaCN, Nal, DMSO, $60{ }^{\circ} \mathrm{C}, 85 \%$
h. TBAF, THF, $84 \%$

i. $m$ CPBA, $\mathrm{NaHCO}_{3}, \mathrm{DCM}, 86 \%$

j. DIBAL-H, DCM, $-78{ }^{\circ} \mathrm{C}$ to $-40{ }^{\circ} \mathrm{C}$,

HO

$59 \%$

Scheme 27: Donaldson's organoiron route towards the guianolide skeleton.

compound 230. Subjection of the trans-cis-divinylcyclopropane mixture to elevated temperature smoothly formed the desired bicycle 231. The less hindered double bond was removed using Wilkinson's catalyst, followed by standard functional group interconversions to yield epoxide 232. When this compound was subjected to oxidative conditions both alcohols were oxidized to the corresponding aldehyde/ketone. Baseinduced epoxide opening led to the formation of a double bond (C4/C5) and concomitant lactol-formation. The lactol was oxidized to the corresponding lactone under the same reaction condition. Final reduction gave core skeleton 233.

\section{DVCPR in tandem reactions}

The group of Stoltz [196,197] succeeded in establishing a tandem Wolff rearrangement/divinylcyclopropane rearrangement strategy [198]. Readily accessible $\alpha$-diazo ketone 234 (see Scheme 28) was shown to undergo Wolff rearrangement [199] upon treatment with silver benzoate. The intermediate ketene 235 underwent stereospecific DVCPR through transition state 235 ' under the reaction conditions to give enone 236 in excellent yield. This constituted the first example of the direct formation of an enone through a DVCPR.

Stephenson and coworker [200] found an intriguing example of a light mediated radical cyclization/arylvinylcyclopropane rearrangement. Subjecting cyclopropyl bromide 237 to an Ir-polypyridyl catalyst and visible light initiated the desired photoredox cascade forming a cyclopropylradical, which readily cyclized in an 5-exo-dig fashion. Radical quenching gave cis-arylvinylcyclopropane 238. Arylvinylcyclopropane rearrangement was followed by rearomatization to give tetracycle 239 (see Scheme 29).
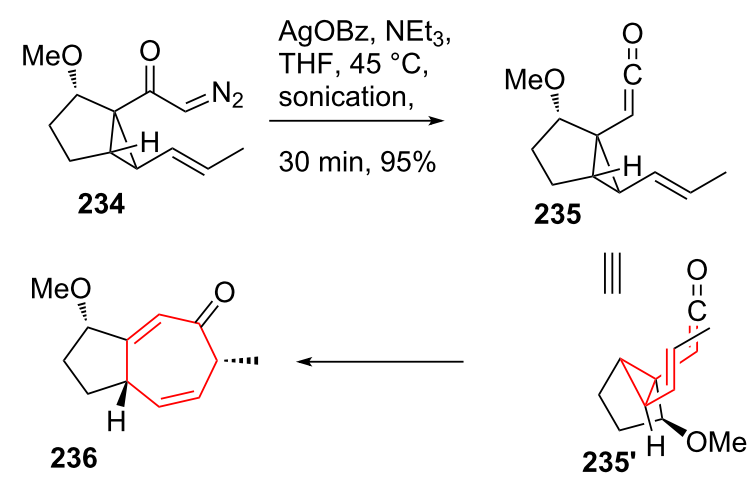

Scheme 28: Stoltz's tandem Wolff/DVCPR rearrangement.

Padwa and coworkers [201] discovered an intermediate DVCPR during their investigation of rhodium-catalyzed cyclizations of alkynyl substituted $\alpha$-diazo ketones. Transition metal-catalyzed diazo-decomposition of compound $\mathbf{2 4 0}$ (see Scheme 30) resulted in the formation of metallacyclobutene 241, followed by rapid metallacycloreversion to give carbenoid species 242. Intramolecular cyclopropanation furnished divinylcyclopropane 243, which underwent DVCPR under these conditions to give tetracycle 244 in 50\% yield.

Matsubara and coworkers [202] investigated the formation of cyclohepta-1,3-diones from 1,2-diketone starting materials. Treatment of $\mathbf{2 4 5}$ with bis(iodozincio)methane resulted in the formation of cis-divinylcyclopropane $\mathbf{2 4 6}$ as the corresponding bis-zinc-enolate species. DVCPR occurred at ambient temperature, final acidic workup provided cycloheptadione 247 in excellent yield (see Scheme 31). 


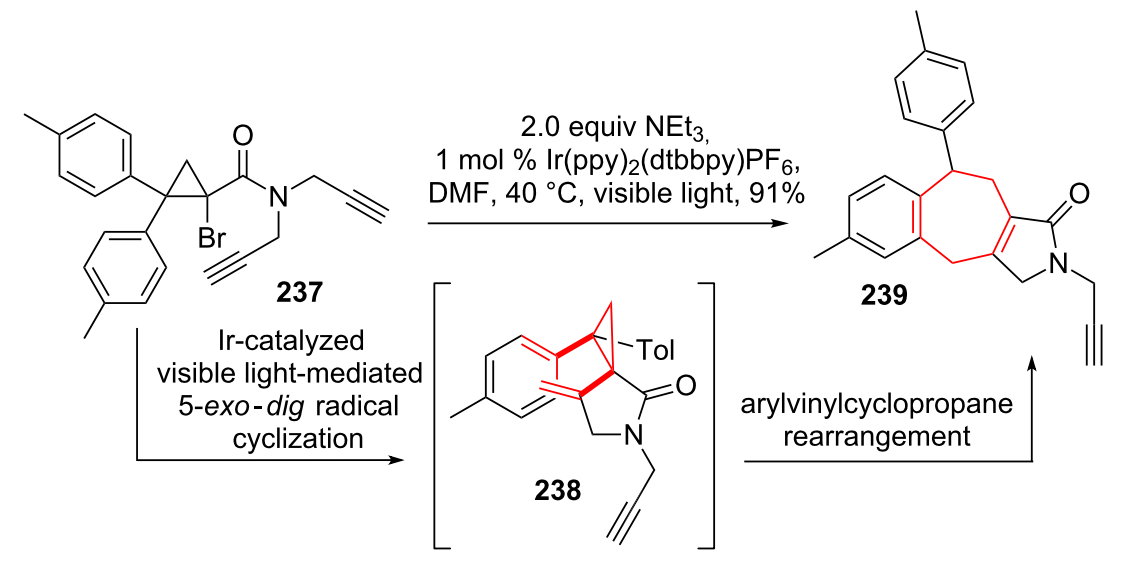

Scheme 29: Stephenson's tandem photocatalysis/arylvinylcyclopropane rearrangement.

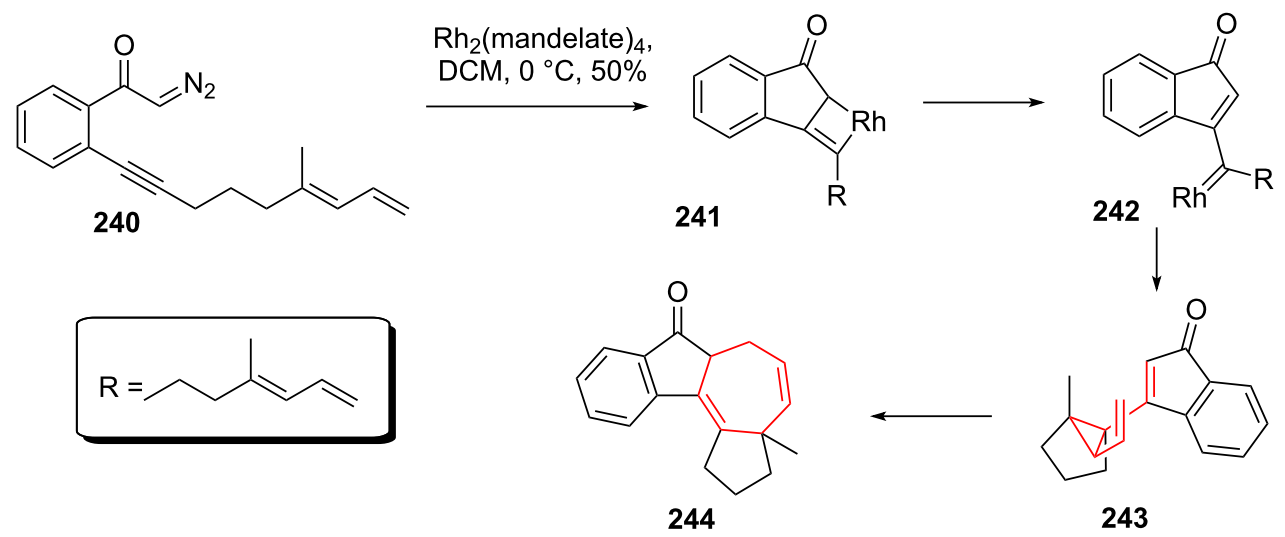

Scheme 30: Padwa's rhodium cascade involving a DVCPR.

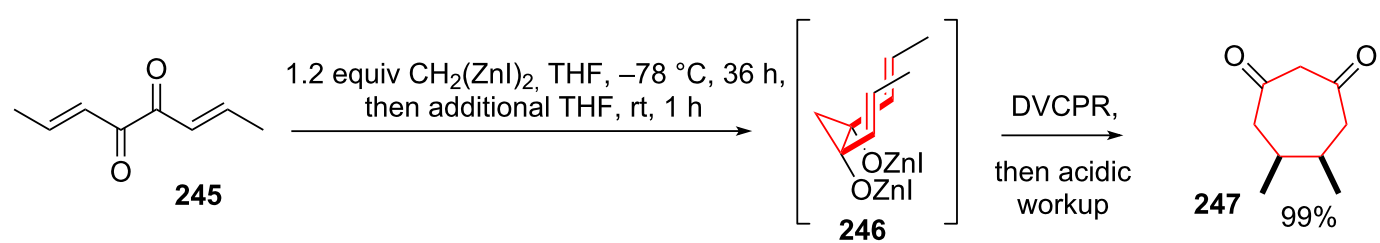

Scheme 31: Matsubara's version of a DVCPR.

Toste and coworkers [203] reported a tandem gold-catalyzed Claisen rearrangement from popargyl vinyl ether 248 (see Scheme 32) to give intermediate vinyl-allenecyclopropane $\mathbf{2 4 9}$, followed by a DVCPR to furnish cycloheptadiene $\mathbf{2 5 0}$.

\section{1,2-Shift and vinyl-carbenoid formation sequences}

Two major pathways to generate divinylcyclopropanes using transition metal catalysis have been developed. Uemura and coworkers [204] were the first to apply the transition metal catalyzed 1,2-acyl shift with subsequent vinyl carbenoid forma- tion. Propargylic acetate 251 (see Scheme 33) has been shown to undergo 5-exo-dig cyclization via $\mathbf{2 5 2}$ to give zwitterionic intermediate 253. A concomitant fragmentation reaction yielded vinyl-carbenoid 254. Uemura and coworkers used this chemistry with propargylic acetate $\mathbf{2 5 5}$ to achieve cyclopropanation with various dienes, for example cyclopentadiene, to generate a cis/trans-mixture of divinylcyclopropanes 256. Heating of this mixture of compounds resulted in the formation of bridged tricycle 257 in good yield. Toste and coworkers [205] discovered a 1,2-pivaloyl shift and cyclopropanation of the resulting 


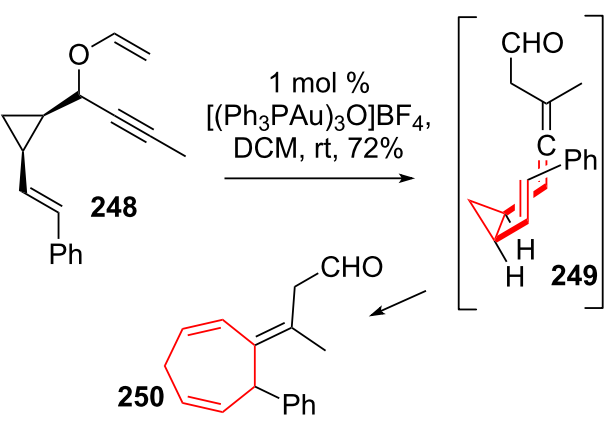

Scheme 32: Toste's tandem gold-catalyzed Claisen-rearrangement/ DVCPR.

gold-carbenoid from $\mathbf{2 5 8}$ with enyne $\mathbf{2 5 9}$ to yield vinylalkynecyclopropane 260. This compound was shown to undergo a gold catalyzed DVCPR to yield 261. Note that this reaction does most likely proceed via a step wise mechanism and involves charged intermediates.

Nevado and coworkers [206] applied a closely related reaction to propargylic acetate $\mathbf{2 6 2}$ using a cationic gold(I) catalyst, which was used to selectively cyclopropanate the less hindered double bond of dienes like 263. Spontaneous DVCPR provided cycloheptadiene 265 via 264 in good yields.

Further contributions to the topic have been put forward by the group of Echavarren [207] and Gung [208].

\section{Cycloisomerization involving DVCPR}

Iwasawa and coworkers [209] discovered a cyclopropanation/ DVCPR sequence of alkyne-substituted silyl enol ethers (for example 274, see Scheme 34) catalyzed by in situ formed $\mathrm{W}(\mathrm{CO})_{5}$ (tol) upon irradiation to give annulated tricycle $\mathbf{2 7 5}$. The common mechanism for this type of reaction proceeds via endo-dig cyclization of enynes like $\mathbf{2 6 6}$ to give zwitterionic intermediate 267. Metal-carbenoid formation with subsequent cyclopropane formation gives rise to either cis- or trans-divinylcyclopropanes 268/271. cis-Divinylcyclopropane 271 can readily undergo DVCPR to give bicycle 272. 1,2-Migration of the migrating group $\mathrm{G}$ leads to final bicycle 273 after regeneration of the catalyst. Trans-divinylcyclopropane 268 can undergo DVCPR after 1,2-migration and subsequent formation of cisdivinylcyclopropane $\mathbf{2 6 9}$ yielding bridged bicycle $\mathbf{2 7 0}$.

Chung and coworkers [210] discovered a related reaction pattern using platinum(II) as the catalyst. Depending on the at-

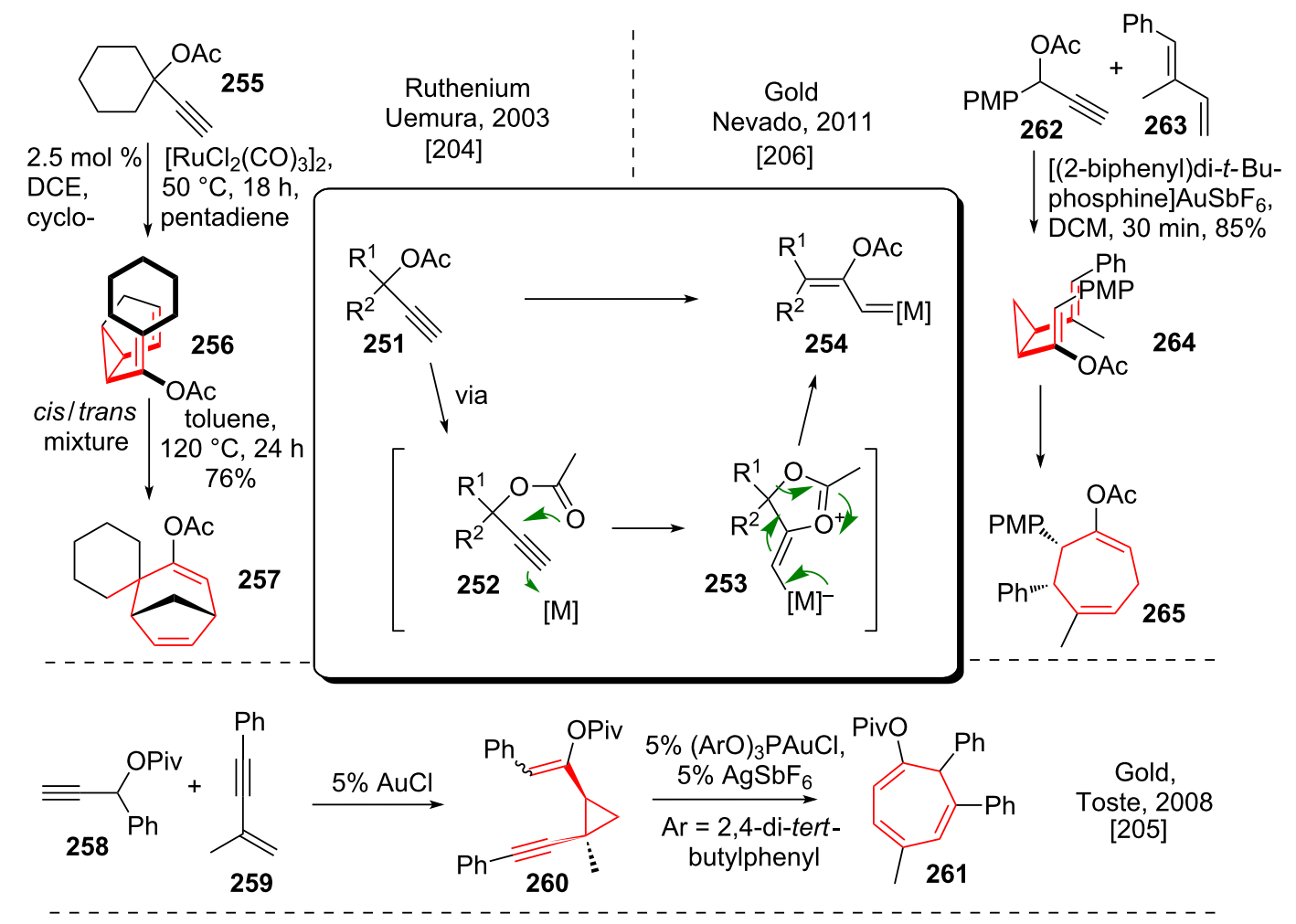



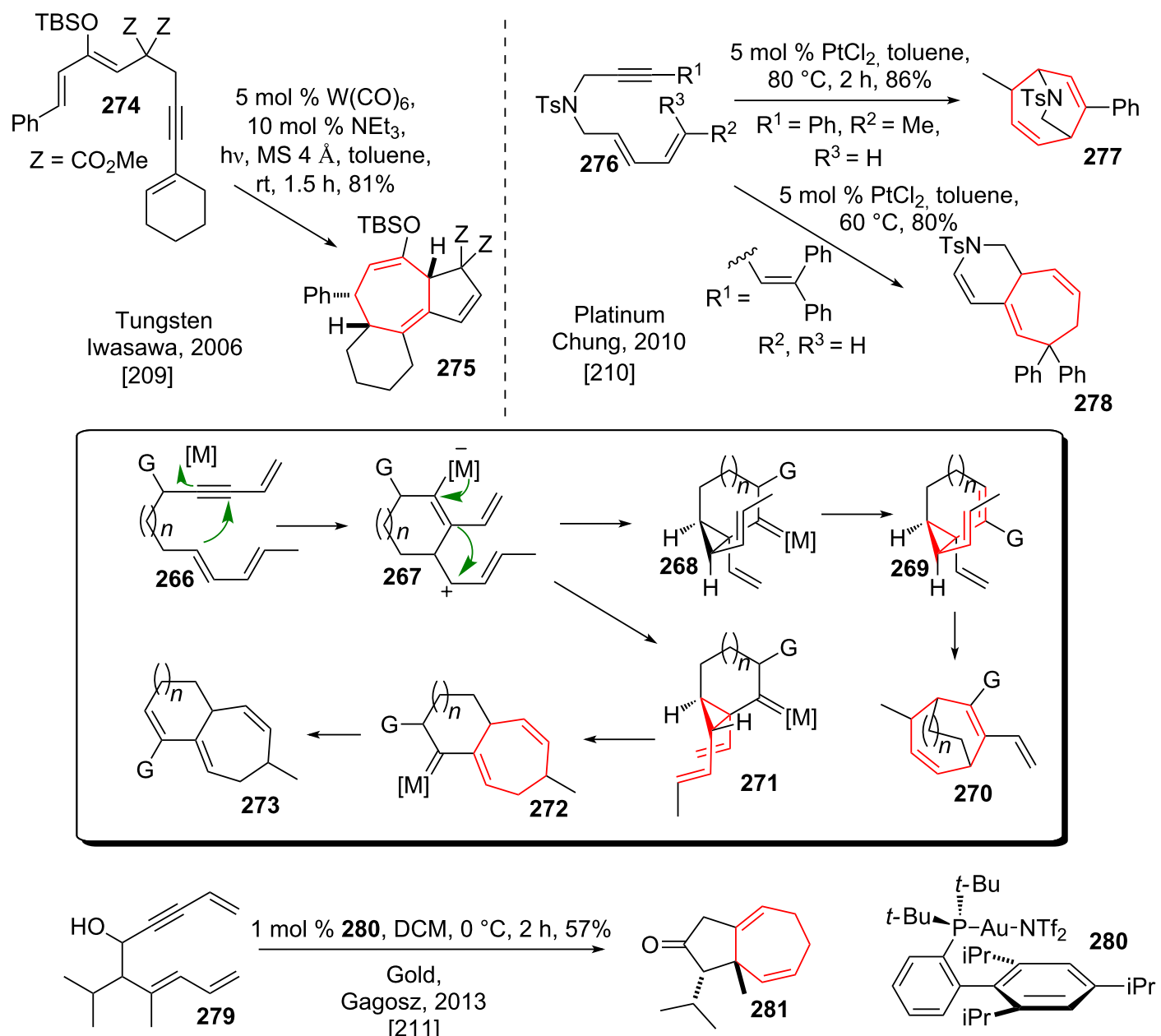

Scheme 34: Tungsten, platinum and gold catalysed cycloisomerizations leading to a DVCPR.

tached rests on enyne $\mathbf{2 7 6}$ both possible cycloheptadienes (bridged $\mathbf{2 7 7}$ or annulated $\mathbf{2 7 8}$ ) could be accessed. The selective formation of annulated bicycle $\mathbf{2 7 8}$ in preference of the possible bridged variant underlined the prefered reactivity of their enyne system.

Gagosz and coworkers [211] recently showed that the cycloisomerization of enynes can be catalyzed by gold(I) catalysts. In a particular striking example propargylic alcohol 279 could be converted into bicyclic ketone $\mathbf{2 8 1}$ in good yields.

\section{Heteroatom variants}

The oxygen substituted versions of the DVCPR have been subject to more intense research in the covered time period than the corresponding nitrogen variants. In general there are two different modes for the heteroatom incorporation into the DVCPR, as part of the cyclopropane moiety or as part of one of the vinyl moieties. All variants are covered in the following.
The Reisman group $[12,212]$ observed an intermediate vinylcyclopropane carbaldehyde rearrangement on their way towards the total synthesis of salvileucalin B (292, see Scheme 35) isolated from the plant Salvia leucantha [213]. Starting from enantiopure trialkyne 282, desilylation was affected using TBAF, followed by ruthenium-catalyzed cycloisomerization [214] and cleavage of the chiral auxiliary to obtain tetracycle 283. The carboxylic acid was converted into the corresponding acyl chloride, followed by addition of diazomethane and subsequent Arndt-Eistert homologation [215] to obtain methyl ester 284. Claisen condensation furnished the intermediate $\beta$-cyanoketone, which was subjected to diazotransfer conditions [216] to obtain $\mathbf{2 8 5}$. This compound underwent smooth cyclopropanation with the adjacent benzene moiety to give cis-vinylcyclopropane cyanide 286. Conversion of the ketone to the corresponding triflate followed by mono-reduction of the nitrile furnished cis-vinylcyclopropane carbaldehyde 287, which underwent smooth, but undesired rearrangement to dihydroox- 

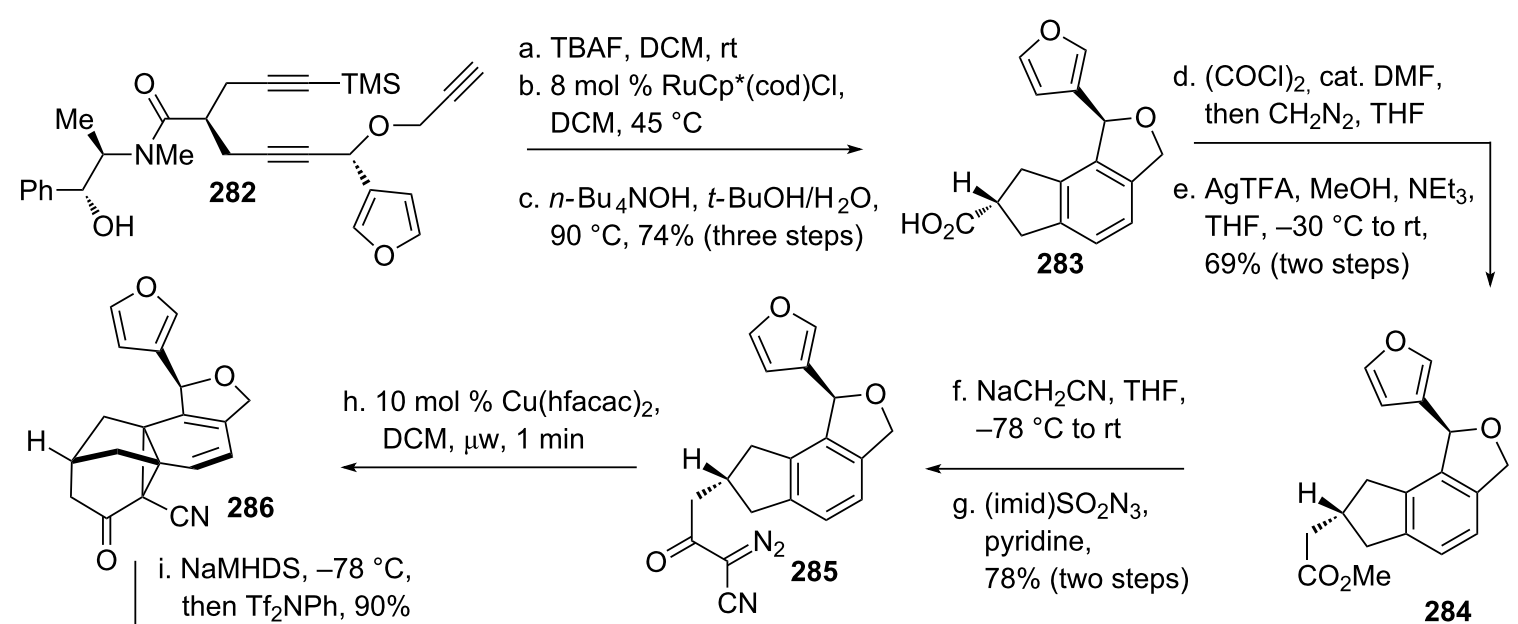

j. DIBAL-H, DCM,

$-40{ }^{\circ} \mathrm{C}$, then aq $\mathrm{AcOH}$
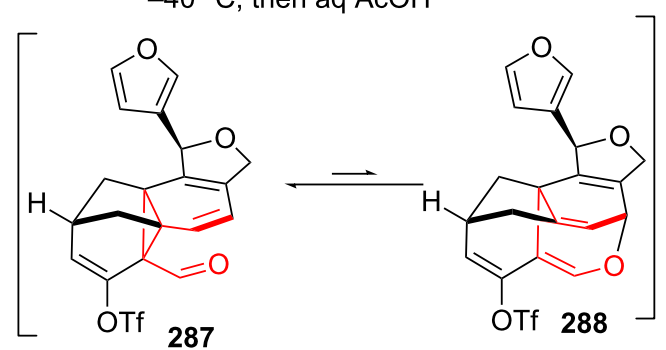

k. DIBAL-H, DCM, $-40^{\circ} \mathrm{C}$ then aq $\mathrm{AcOH}$ $57 \%$ (two steps)

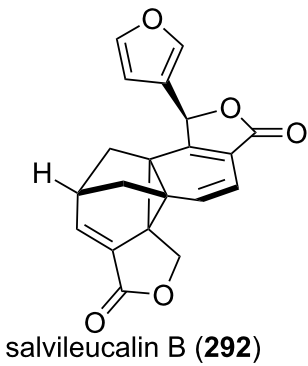

m. $291, \mathrm{DCM},-35^{\circ} \mathrm{C}, 51 \%$

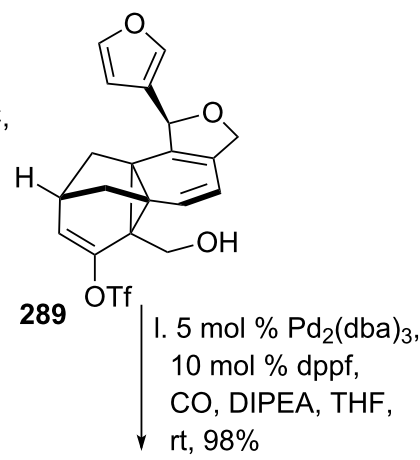

salvileucalin B (292)
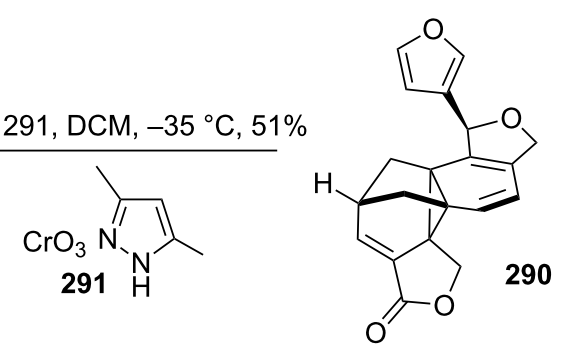

Scheme 35: Reisman's total synthesis of salvileucalin B, featuring an (undesired) vinylcyclopropyl carbaldehyde rearrangement.

epin 288. This rearrangement has been observed to be reversible [217]. Treatment with DIBAL-H reduced the carbaldehyde moiety selectively to give alcohol 289. Lactonization was achieved upon Pd-catalyzed CO-insertion to give 290. The desired natural product was obtained after oxidation of the tetrahydrofuran to the desired natural product salvileucalin B (292) using chromium trioxide·3,5-dimethylpyrazole [218].

\section{Oxygen variants overview}

The divinyloxirane rearrangement (293 to 294, see Scheme 36) has been investigated in detail by the groups of White and Smith $[219,220]$. The synthesis of the cyclization precursors started from enynes like 297, beginning with cis-selective Rieke-Zn reduction. Epoxidation followed by oxidation furnished cis-vinylketone-epoxide 298. Enolate formation and acetate trapping afforded an intermediate enol-acetate, which underwent high-yielding cis-divinylepoxide rearrangement at elevated temperatures to yield dihydrooxepine 299 in good yield. De Meijere and coworkers [221] investigated the selective epoxidation of hexatrienes like $\mathbf{3 0 0}$ to yield cis-divinylepoxide 301. Gentle heating provided bridged bicycle 302, containing two-anti-Bredt olefins in a stereospecific reaction. Doyle and coworkers [222] succeeded in preparing transdivinylcyclopropanes like 304 via rhodium-catalyzed vinyldiazo decomposition (using compound 101) and subsequent epoxide formation in the presence of cinnamon aldehyde (303). These rather stable epoxides (see 304) were shown to undergo trans-cis isomerization followed by divinylepoxide rearrange- 


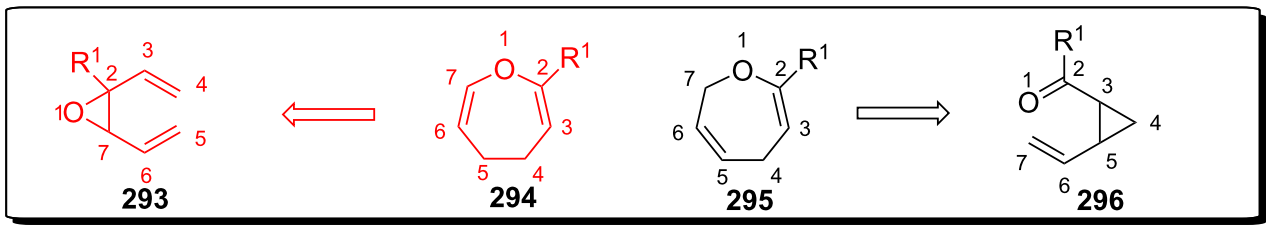

White \& Smith, starting 1990

$[219,220]$

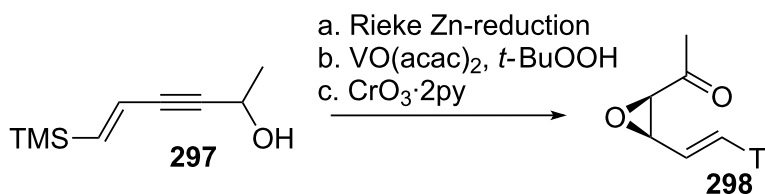

d. LiHMDS, THF, $-70^{\circ} \mathrm{C}$, then $\mathrm{Ac}_{2} \mathrm{O}, 70 \%$

e. $\mathrm{CCl}_{4}, 135^{\circ} \mathrm{C}, 12 \mathrm{~h}, 94 \%$

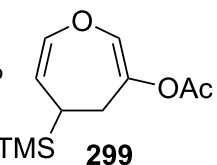

de Meijere, 1999

[221]

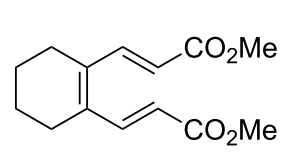

300

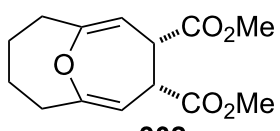

302

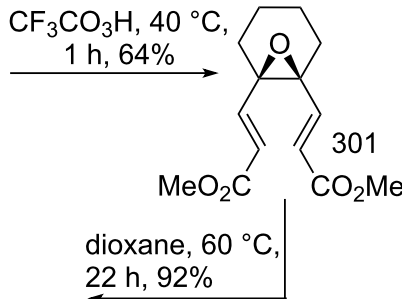

$22 \mathrm{~h}, 92 \%$

\section{Doyle, 2011}

[222]
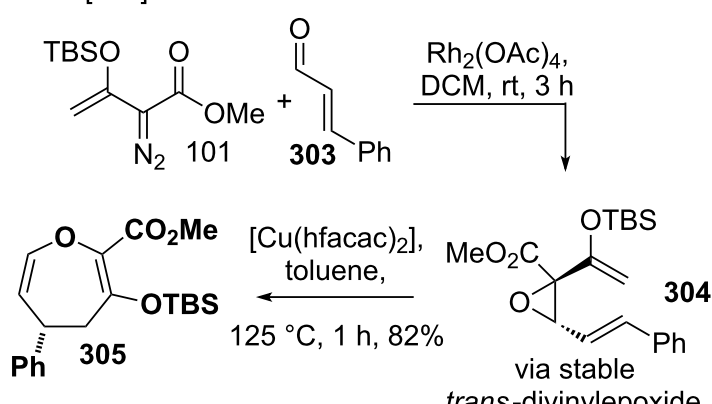

Scheme 36: Studies on the divinylepoxide rearrangement.

ment to give dihydrooxepine 305 at $125^{\circ} \mathrm{C}$. The necessary reaction temperature could be lowered using copper(II) catalysis, accelerating the reaction rate as well.

The vinylepoxide-carbaldehyde rearrangement ( 295 to 296 , see Scheme 37) has been investigated early on by the group of Boeckmann [217]. Dess-Martin periodinane oxidation of diol
306 resulted in a smooth rearrangement at ambient temperature, yielding formyldihydrooxepine $\mathbf{3 0 7}$.

A modified approach has been investigated by the group of Lee, using transition metal mediated diazo decomposition [223]. The in situ generated rhodium-carbenoid formed upon diazo decomposition of $\mathbf{3 0 8}$ underwent cyclopropanation with butadi-<smiles>[R]C1=CC([R4])CCC=[C]O1</smiles><smiles>[R]C1=CCC=CCO1</smiles><smiles>[R]C(=O)C1CC1C=C</smiles>

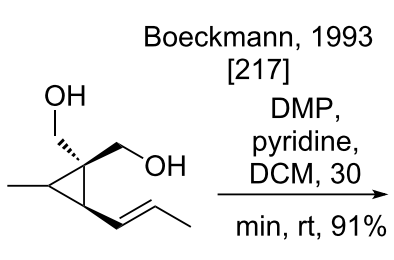

306

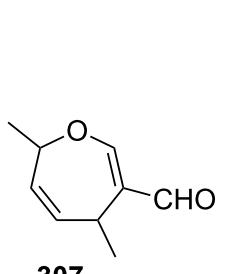

307<smiles>CC(I)C1CC(=O)C(=N)C(=O)C1</smiles>

Lee, 2005

223]

$0.5 \mathrm{~mol} \%$

$\mathrm{Rh}_{2}$ (OPiv) $\stackrel{\mathrm{rt}, 3 \mathrm{~h}, 69 \%}{\mathrm{~L}}$<smiles>CC1=C(C)CC2=C(CC(C(C)C)CC2=O)OC1</smiles>

310 
enes like 309. The resulting vinyl-epoxide ketone underwent rearrangement to give dihydrooxepine $\mathbf{3 1 0}$ in good yield. Vinylcyclopropane-cyclopentene rearrangement [13,14] has been shown to be the major competing side reaction in this case.

\section{Nitrogen variants}

Three different approaches can be used to incorporate nitrogen into the DVCPR. The cis-divinylaziridine rearrangement (311 to $\mathbf{3 1 2}$, see Scheme 38) after rhodium-catalyzed aziridine formation between vinyl-diazo compound $\mathbf{3 1 7}$ and imine $\mathbf{3 1 8}$ has been found by Doyle [224-226]. Rearrangement occurred smoothly to give desired dihydroazepine 320. Note that the authors suggest a transition state including an opened aziridine zwitterion. Alternatively, a cyclopropylamine can be used in an iminium ion type DVCPR rearrangement (313 to $\mathbf{3 1 4}$, see Scheme 38 ), or a cyclopropylcarbaldehyde can be condensed with an amine to an imine, which then undergoes the DVCPR rearrangement (315 to 316, see Scheme 38). Müller and coworkers [227,228] investigated the trans-vinylisocyanato-cyclopropyl rearrangement in great detail. Electrocycloreversion of initialy formed nitrene $\mathbf{3 2 1}$ leads to intermediate 322 , which can undergo electrocyclization to give the required trans-vinylisocyanatocyclopropane 323 , which underwent the desired rearrangement to give tricycle 324. The group of Boeckman pioneered the heteroatom variants of the DVCPR, namely the vinylcyclopropane carbaldehyde-dihydrooxepine rearrangement [217], the vinylcyclopropane carbimine-dihydroazepine [217] rearrangement and the corresponding cyclobutane analogues [229-231]. A very stunning application [231] has been achieved using the Claisen reaction of dihydrooxepine 325 (see Scheme 38) to access vinylcyclopropane carbaldehyde 326, which was in situ converted into the corresponding imine 327 using an aza-Wittig reaction. Subsequent vinylcyclopropane carbimine-dihydroazepine rearrangement furnished cyclic $\mathbf{3 2 8}$ in excellent yield.

\section{Conclusion}

The divinylcyclopropane-cycloheptadiene rearrangement has been developed as a versatile method for the construction of seven-membered rings. The utilization in the total synthesis of both sesqui- and diterpenoid natural products as well as in the total synthesis of alkaloids and fatty acid-derived metabolites underlines its robustness and broad applicability. Contribution of the DVCPR as the key step to the solution of some of the most daunting synthetic challenges in present synthetic organic chemistry make it the tool of choice when constrained and highly substituted seven-membered rings are involved. The development of the formal [4 +3$]$-cycloaddition (using a tandem cyclopropanation/DVCPR) has largely added to the scope of natural products that were synthesized using a DVCPR and shortened the overall synthetic routes.
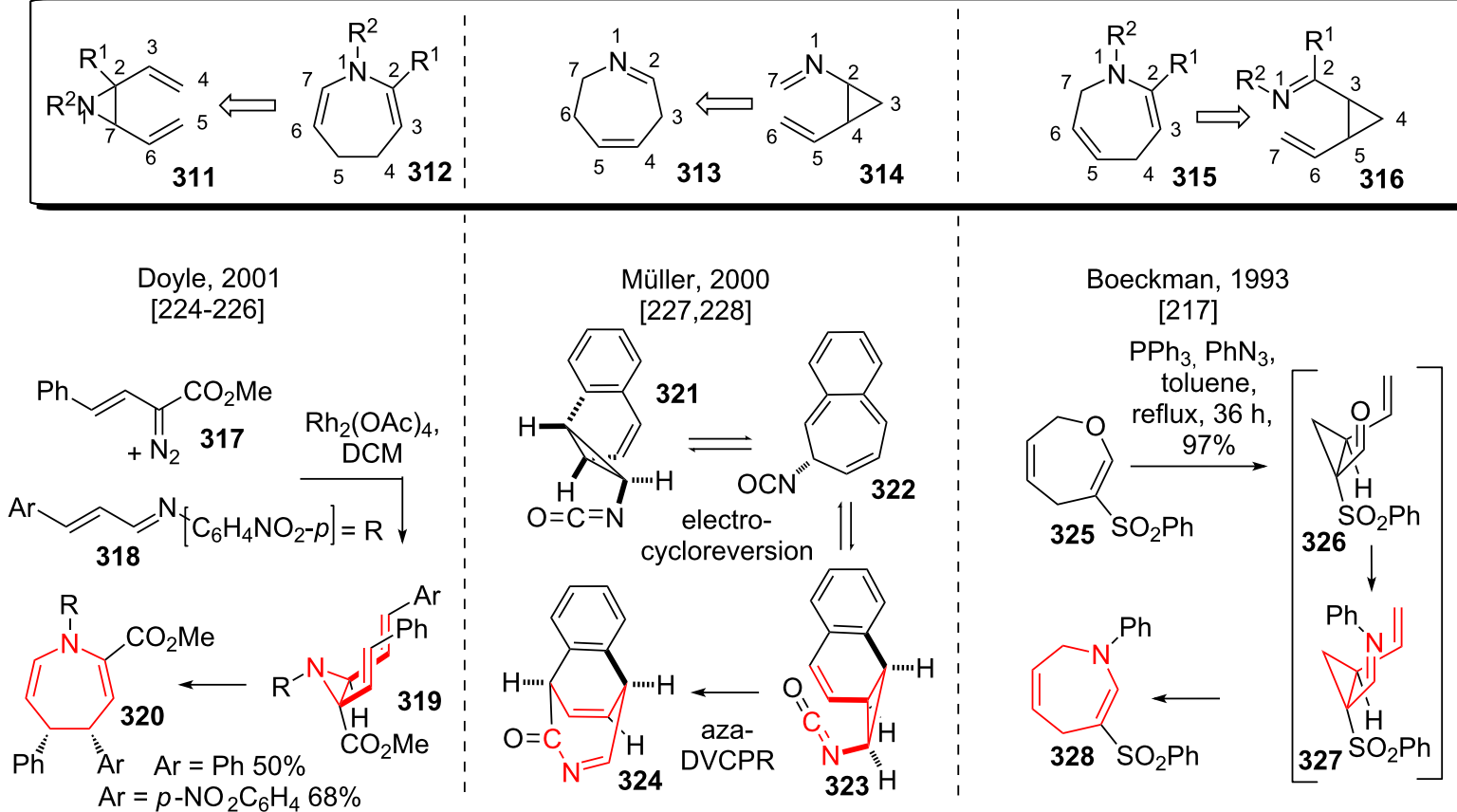


\section{References}

1. Vogel, E. Angew. Chem. 1960, 72, 4-26. doi:10.1002/ange.19600720103

2. Vogel, E.; Ott, K.-H.; Gajek, K. Justus Liebigs Ann. Chem. 1961, 644, 172-188. doi:10.1002/jlac.19616440121

3. Brown, J. M.; Golding, B. T.; Stofko, J. J. J. Chem. Soc., Chem. Commun. 1973, 319-320. doi:10.1039/C3973000319B

4. Hofmann, K.; Orochena, S. F.; Sax, S. M.; Jeffrey, G. A. J. Am. Chem. Soc. 1959, 81, 992-997. doi:10.1021/ja01513a059

5. Hudlicky, T.; Fan, R.; Reed, J. W.; Gadamasetti, K. G. Org. React. 1992, 4, 1-133. doi:10.1002/0471264180.or041.01

6. Piers, E. In Comprehensive Organic Synthesis; Trost, B. M.; Fleming, I.; Paquette, L. A., Eds.; Pergamon Press: Oxford, 1991; Vol. 5, pp 971-988. doi:10.1016/B978-0-08-052349-1.00143-8

7. Tang, P.; Qin, Y. Synthesis 2012, 44, 2969-2984. doi:10.1055/s-0032-1317011

8. Evans, A. P., Ed. Modern Rhodium Catalyzed Reactions; Wiley-VCH: Weinheim, 2005. doi:10.1002/3527604693

9. Lin, H.; Danishefsky, S. J. Angew. Chem., Int. Ed. 2003, 42, 36-51. doi:10.1002/anie.200390048

10. Davies, H. M. L.; Denton, J. R. Chem. Soc. Rev. 2009, 38, 3061-3071. doi:10.1039/b901170f

11. Buchner, E.; Curtius, T. Ber. Dtsch. Chem. Ges. 1885, 18, 2377-2379. doi:10.1002/cber.188501802119

12. Reisman, S. E.; Nani, R. R.; Levin, S. Synlett 2011, 2437-2442. doi:10.1055/s-0031-1289520

13. Goldschmidt, Z.; Crammer, B. Chem. Soc. Rev. 1988, 17, 229-267. doi:10.1039/cs9881700229

14. Hudlicky, T.; Reed, J. W. Angew. Chem., Int. Ed. 2010, 49, 4864-4876. doi:10.1002/anie.200906001

15. Tantillo, D. J.; Hoffmann, R. J. Org. Chem. 2002, 67, 1419-1426. doi:10.1021/jo0107002

16. Doering, W. V. E.; Roth, W. R. Angew. Chem. 1963, 75, 27-35. doi:10.1002/ange.19630750106

17. Özkan, I.; Zora, M. J. Org. Chem. 2003, 68, 9635-9642. doi:10.1021/jo035173w

18. Zora, M.; Özkan, I.; Danisman, M. F. J. Mol. Struct.: THEOCHEM 2003, 636, 9-13. doi:10.1016/S0166-1280(03)00478-0

19. Zora, M. J. Mol. Struct.: THEOCHEM 2004, 681, 113-116. doi:10.1016/j.theochem.2004.05.011

20. Von E. Doering, W.; Roth, W. R. Tetrahedron 1963, 19, 715-737. doi:10.1016/S0040-4020(01)99207-5

21. Klärner, F.-G.; Jones, M., Jr.; Magid, R. M. Acc. Chem. Res. 2009, 42, 169-181. doi:10.1021/ar800100h

22. Zora, M. J. Org. Chem. 2005, 70, 6018-6026. doi:10.1021/jo050711।

23. Zora, M.; Özkan, I. J. Mol. Struct.: THEOCHEM 2003, 625, 251-256. doi:10.1016/S0166-1280(03)00073-3

24. Sperling, D.; Reißig, H.-U.; Fabian, J. Liebigs Ann. 1997, 2443-2449. doi:10.1002/jlac.199719971207

25. Sperling, D.; Reißig, H.-U.; Fabian, J. Eur. J. Org. Chem. 1999, 1107-1114. doi:10.1002/(SICI)1099-0690(199905)1999:5<1107::AID-EJOC1107> 3.0.CO;2-E

26. Schneider, M. P.; Csacsko, B. J. Chem. Soc., Chem. Commun. 1977, 330-331. doi:10.1039/C39770000330

27. Arai, M.; Crawford, R. J. Can. J. Chem. 1972, 50, 2158-2162. doi:10.1139/v72-348

28. Baldwin, J. E.; Ullenius, C. J. Am. Chem. Soc. 1974, 96, 1542-1547. doi:10.1021/ja00812a044
29. Baldwin, J. E.; Gilbert, K. E. J. Am. Chem. Soc. 1976, 98, 8283-8284. doi:10.1021/ja00441a078

30. Pohnert, G.; Boland, W. Tetrahedron 1997, 53, 13681-13694. doi:10.1016/S0040-4020(97)00886-7

31. Boland, W.; Pohnert, G.; Maier, I. Angew. Chem., Int. Ed. Engl. 1995, 34, 1602-1604. doi:10.1002/anie.199516021

32. Müller, D. G.; Jaenicke, L.; Donike, M.; Akintobi, T. Science 1971, 171, 815-817. doi:10.1126/science.171.3973.815

33. Hortmann, A. G. Tetrahedron Lett. 1968, 9, 5785-5786. doi:10.1016/S0040-4039(00)76350-7

34. Hortmann, A. G.; Danile, D. S.; Martinelli, J. E. J. Org. Chem. 1973, 38, 728-735. doi:10.1021/jo00944a024

35. Tomita, B.; Hirose, Y. Tetrahedron Lett. 1970, 11, 235-238. doi:10.1016/0040-4039(70)80034-X

36. Cox, P. J.; Sim, G. A.; Roberts, J. S.; Herz, W. J. Chem. Soc., Chem. Commun. 1973, 428-429. doi:10.1039/C39730000428

37. Sun, H. H.; Waraszkiewicz, S. M.; Erickson, K. L.; Finer, J.; Clardy, J. J. Am. Chem. Soc. 1977, 99, 3516-3517. doi:10.1021/ja00452a062

38. Schwarzer, D. D.; Gritsch, P. J.; Gaich, T. Angew. Chem., Int. Ed. 2012, 51, 11514-11516. doi:10.1002/anie.201203586

39. Schwarzer, D. D.; Gritsch, P. J.; Gaich, T. Synlett 2013, 24, 1025-1031. doi:10.1055/s-0032-1318501

40. Floss, H. G. Tetrahedron 1976, 32, 873-912. doi:10.1016/0040-4020(76)85047-8

41. Wenkert, E.; Sliwa, H. Bioorg. Chem. 1977, 6, 443-452. doi:10.1016/0045-2068(77)90043-8

42. Seiler, M. P. Ph.D. Dissertation No. 4574, ETH Zürich, 1970.

43. Marvell, E. N.; Crystal, L. J. Am. Chem. Soc. 1978, 100, 877-883. doi:10.1021/ja00471a036

44. Ito, H.; Takeguchi, S.; Kawagishi, T.; Iguchi, K. Org. Lett. 2006, 8, 4883-4885. doi:10.1021/ol061947u

45. Iwashima, M.; Terada, I.; Okamoto, K.; Iguchi, K. J. Org. Chem. 2002, 67, 2977-2981. doi:10.1021/jo011043g

46. Murga, J.; Garcia-Fortanet, J.; Carda, M.; Marco, J. A. Synlett 2004, 2830-2832. doi:10.1055/s-2004-835653

47. Wender, P. A.; Eissenstat, M. A.; Filosa, M. P. J. Am. Chem. Soc. 1979, 101, 2196-2198. doi:10.1021/ja00502a042

48. Wender, P. A.; Filosa, M. P. J. Org. Chem. 1976, 41, 3490-3491. doi:10.1021/jo00883a043

49. Piers, E.; Moss, N. Tetrahedron Lett. 1985, 26, 2735-2738. doi:10.1016/S0040-4039(00)94898-6

50. Piers, E.; Jung, G. L. Can. J. Chem. 1987, 65, 1668-1671. doi:10.1139/v87-279

51. Piers, E.; Jean, M.; Marrs, P. S. Tetrahedron Lett. 1987, 28 5075-5078. doi:10.1016/S0040-4039(00)95593-X

52. Ranieri, R. L.; Calton, G. J. Tetrahedron Lett. 1978, 19, 499-502. doi:10.1016/S0040-4039(01)85316-8

53. Calton, G. J.; Ranieri, R. L.; Espenshade, M. A. J. Antibiot. 1978, 31, 38-42. doi:10.7164/antibiotics.31.38

54. Kubiak, G.; Cook, J. M.; Weiss, U. J. Org. Chem. 1984, 49, 561-564. doi:10.1021/jo00177a040 Obtained from monopreotection of the diketone according to this reference.

55. Burke, S. D.; Murtiashaw, C. W.; Saunders, J. O.; Oplinger, J. A.; Dike, M. S. J. Am. Chem. Soc. 1984, 106, 4558-4566. doi:10.1021/ja00328a043

56. Burke, S. D.; Murtiashaw, C. W.; Oplinger, J. A. Tetrahedron Lett. 1983, 24, 2949-2952. doi:10.1016/S0040-4039(00)88066-1 
57. Burke, S. D.; Murtiashaw, C. W.; Saunders, J. O.; Dike, M. S. J. Am. Chem. Soc. 1982, 104, 872-874. doi:10.1021/ja00367a049

58. Beechan, C. M.; Djerassi, C.; Finer, J. S.; Clardy, J. Tetrahedron Lett. 1977, 18, 2395-2398. doi:10.1016/S0040-4039(01)83775-8

59. Andersen, N. H.; Falcone, M. S. Chem. Ind. (London) 1971, 62-63.

60. Carrol, P. J.; Ghisalberti, E. L.; Ralph, D. E. Phytochemistry 1976, 15, 777-780. doi:10.1016/S0031-9422(00)94442-X

61. Crandall, J. K.; Baker, D. B.; Colyer, R. A.; Watkins, R. J.; Arrington, J. P. J. Org. Chem. 1968, 33, 423-425. doi:10.1021/jo01265a089 Obtained after TBS-protection of the alcohol.

62. Overman, L. E.; Ricca, D. J.; Tran, V. D. J. Am. Chem. Soc. 1993, 115, 2042-2044. doi:10.1021/ja00058a064

63. Abelman, M. M.; Overman, L. E. J. Am. Chem. Soc. 1988, 110, 2328-2329. doi:10.1021/ja00215a068

64. Kucera, D. J.; O'Connor, S. J.; Overman, L. E. J. Org. Chem. 1993, 58, 5304-5306. doi:10.1021/j000072a006

65. Overman, L. E.; Ricca, D. J.; Tran, V. D. J. Am. Chem. Soc. 1997, 119, 12031-12040. doi:10.1021/ja972427k

66. Hayashi, T.; Kishi, M.; Kawasaki, M.; Arisawa, M.; Shimizu, M.; Suzuki, S.; Yoshizaki, M.; Morita, N.; Tezuka, Y.; Kikuchi, T.; Berganza, L. H.; Ferro, E.; Basualdo, I. Tetrahedron Lett. 1987, 28, 3693-3696. doi:10.1016/S0040-4039(00)96357-3

67. Skattebøl, J. J. Org. Chem. 1964, 29, 2951-2956. doi:10.1021/jo01033a035

68. Seyferth, D.; Yamazaki, H.; Alleston, D. L. J. Org. Chem. 1963, 28 , 703-706. doi:10.1021/jo01038a025

69. Grigg, R.; Sridharan, V.; Stevenson, P.; Worakun, T. J. Chem. Soc., Chem. Commun. 1986, 1697-1699. doi:10.1039/C39860001697

70. Abelman, M. M.; Oh, T.; Overman, L. E. J. Org. Chem. 1987, 52, 4130-4133. doi:10.1021/jo00227a038

71. Overman, L. E.; Abelmann, M. M.; Kucera, D. J.; Tran, V. D.; Ricca, D. J. Pure Appl. Chem. 1992, 64, 1813-1819. doi:10.1351/pac199264121813

72. Osuka, A.; Taka-Oka, K.; Suzuki, H. Chem. Lett. 1984, 13, 271-272. doi:10.1246/cl.1984.271

73. Solomon, M.; Jamison, W. C. L.; McCormick, M.; Liotta, D.; Cherry, D. A.; Mills, J. E.; Shah, R. D.; Rodgers, J. D.; Maryanoff, C. A. J. Am. Chem. Soc. 1988, 110, 3702-3704. doi:10.1021/ja00219a079

74. Panetta, C. A.; Dixit, A. S. Synthesis 1981, 59-60. doi:10.1055/s-1981-29337

75. Meyer, N.; Seebach, D. Chem. Ber. 1980, 113, 1304-1319. doi:10.1002/cber.19801130410

76. Taber, D. F. J. Org. Chem. 1976, 41, 2649-2650 doi:10.1021/jo00877a033

77. Hook, J. M.; Mander, L. N.; Woolias, M. Tetrahedron Lett. 1982, 23, 1095-1098. doi:10.1016/S0040-4039(00)87030-6

78. Nagata, W.; Yoshiaka, M. Org. React. 1977, 25, 255-476.

79. Chong, J. M.; Sharpless, K. B. J. Org. Chem. 1985, 50, 1560-1563. doi:10.1021/jo00209a048

80. Carlsen, P. H. J.; Katsuki, T.; Martin, V. S.; Sharpless, K. B. J. Org. Chem. 1981, 46, 3936-3938. doi:10.1021/jo00332a045

81. Fox, M. E.; Li, C.; Marino, J. P., Jr.; Overman, L. E. J. Am. Chem. Soc. 1999, 121, 5467-5480. doi:10.1021/ja990404v

82. Davies, H. M. L.; Doan, B. D. J. Org. Chem. 1998, 63, 657-660. doi:10.1021/jo971577a

83. Davies, H. M. L. In Advances in Cycloadditions; Hermata, M., Ed.; JAI Press: Greenwich, CT, 1998; Vol. 5, pp 119-164.
84. Ayer, W. A.; Cruz, E. R. J. Org. Chem. 1993, 58, 7529-7534. doi:10.1021/jo00078a035

85. Fairlie, D. P.; Bosnich, B. Organometallics 1988, 7, 936-945. doi:10.1021/om00094a025

86. Davies, H. M. L.; Cantrell, W. R.; Romines, K. R.; Baum, J. S. Org. Synth. 1992, 70, 93-97.

87. Davies, H. M. L. Tetrahedron 1993, 49, 5203-5223. doi:10.1016/S0040-4020(01)82371-1

88. Davies, H. M. L.; Bruzinski, P. R.; Lake, D. H.; Kong, N.; Fall, M. J. J. Am. Chem. Soc. 1996, 118, 6897-6907. doi:10.1021/ja9604931

89. Davies, H. M. L.; Doan, B. D. Tetrahedron Lett. 1996, 37, 3967-3970. doi:10.1016/0040-4039(96)00723-X

90. Osborn, J. A.; Jardine, F. H.; Young, J. F.; Wilkinson, G. J. Chem. Soc. A 1966, 1711-1732. doi:10.1039/j19660001711

91. Olson, J. P.; Davies, H. M. L. Org. Lett. 2008, 10, 573-576. doi:10.1021/ol702844g

92. Olson, J. P.; Davies, H. M. L. Org. Lett. 2010, 12, 1144 doi:10.1021/ol100111w

93. Patil, A. D.; Freyer, A. J.; Killmer, L.; Offen, P.; Carte, B.; Jurewicz, A. J.; Johnson, R. K. Tetrahedron 1997, 53, 5047-5060. doi:10.1016/S0040-4020(97)00205-6

94. Yang, D.; Zhang, C. J. Org. Chem. 2001, 66, 4814-4818. doi:10.1021/jo010122p

95. Inoue, M.; Frontier, A. J.; Danishefsky, S. J. Angew. Chem., Int. Ed. 2000, 39, 761-764. doi:10.1002/(SICI)1521-3773(20000218)39:4<761::AID-ANIE761>3.0. $\mathrm{CO} ; 2-\mathrm{I}$

96. Inoue, M.; Carson, M. W.; Frontier, A. J.; Danishefsky, S. J. J. Am. Chem. Soc. 2001, 123, 1878-1889. doi:10.1021/ja0021060

97. Lian, Y.; Miller, L. C.; Born, S.; Sarpong, R.; Davies, H. M. L. J. Am. Chem. Soc. 2010, 132, 12422-12425. doi:10.1021/ja103916t

98. Rudi, A.; Kashman, Y. J. Nat. Prod. 1992, 55, 1408-1414. doi:10.1021/np50088a004

99. Rudi, A.; Shalom, H.; Schleyer, M.; Benayahu, Y.; Kashman, Y. J. Nat. Prod. 2004, 67, 106-109. doi:10.1021/np030261x

100.Gevorgyan, V.; Rubin, M.; Benson, S.; Liu, J.-X.; Yamamoto, Y. J. Org. Chem. 2000, 65, 6179-6186. doi:10.1021/jo000726d

101.Schwartz, B. D.; Denton, J. R.; Lian, Y.; Davies, H. M. L.; Williams, C. M. J. Am. Chem. Soc. 2009, 131, 8329-8332. doi:10.1021/ja9019484

102.Davies, H. M. L.; Loe, Ø.; Stafford, D. G. Org. Lett. 2005, 7, 5561-5563. doi:10.1021/ol052005c

103. Schwartz, B. D.; Denton, J. R.; Davies, H. M. L.; Williams, C. M. Aust. J. Chem. 2009, 62, 980-982. doi:10.1071/CH09267 See for the total synthesis of vibsanin $E$.

104.Fukuyama, Y.; Minami, H.; Matsuo, A.; Kitamura, K.; Akizuki, M.; Kubo, M.; Kodama, M. Chem. Pharm. Bull. 2002, 50, 368-371. doi: $10.1248 / \mathrm{cpb} .50 .368$

105. Mander, L. N.; Thomson, R. J. J. Org. Chem. 2005, 70, 1654-1670. doi:10.1021/jo048199b

106. Anders, E.; Gassner, T. Angew. Chem., Int. Ed. Engl. 1982, 21, 289-290. doi:10.1002/anie.198202891

107.Anders, E.; Gassner, T. Angew. Chem. Suppl. 1982, 675-685.

108. Anders, E.; Gassner, T. Angew. Chem., Int. Ed. Engl. 1983, 22, 619-620. doi:10.1002/anie.198306191

109.Schwartz, B. D.; Williams, C. M.; Anders, E.; Bernhardt, P. V. Tetrahedron 2008, 64, 6482-6487. doi:10.1016/j.tet.2008.04.068

110.Gaydou, M.; Miller, R. E.; Delpont, N.; Ceccon, J.; Echavarren, A. M. Angew. Chem., Int. Ed. 2013, 52, 6396-6399. doi:10.1002/anie.201302411 
111.Ma, W.-H.; Huang, H.; Zhou, P.; Chen, D.-F. J. Nat. Prod. 2009, 72, 676-678. doi:10.1021/np8007864

112.Davies, H. M. L.; Huby, N. J. S. Tetrahedron Lett. 1992, 33, 6935-6938. doi:10.1016/S0040-4039(00)60899-7

113. Carrol, F. I.; Lewin, A. H.; Boja, J. W.; Kuhar, M. J. J. Med. Chem. 1992, 35, 969-981. doi:10.1021/jm00084a001 See for a further reading.

114.Clarke, R. L.; Daum, S. J.; Gambino, A. J.; Aceto, M. D.; Pearl, J.; Levitt, M.; Cumiskey, W. R.; Bogado, E. F. J. Med. Chem. 1973, 16, 1260-1267. doi:10.1021/jm00269a600

115.Davies, H. M. L.; Saikali, E.; Young, W. B. J. Org. Chem. 1991, 56, 5696-5700. doi:10.1021/jo00019a044

116. Davies, H. M. L.; Hougland, P. W.; Cantrell, W. R., Jr. Synth. Commun. 1992, 22, 971-978. doi:10.1080/00397919208019285

117.Davies, H. M. L.; Cantrell, W. R., Jr. Tetrahedron Lett. 1991, 32, 6509-6512. doi:10.1016/0040-4039(91)80206-L

118.Fukuyama, T.; Gang, L. J. Am. Chem. Soc. 1996, 118, 7426-7427. doi:10.1021/ja961701s

119. Fukuyama, T.; Liu, G. Pure Appl. Chem. 1997, 69, 501-506. doi:10.1351/pac199769030501

120. Yokoshima, S.; Tokuyama, H.; Fukuyama, T. Angew. Chem., Int. Ed. 2000, 39, 4073-4075. doi:10.1002/1521-3773(20001117)39:22<4073::AID-ANIE4073>3.0.C $\mathrm{O} ; 2-\mathrm{V}$

121.Lovell, F. M.; Pepinsky, R.; Wilson, A. J. C. Tetrahedron Lett. 1959, 1, 1-5. doi:10.1016/S0040-4039(01)82717-9

122. Conroy, H.; Chakrabarti, J. K. Tetrahedron Lett. 1959, 1, 6-13. doi:10.1016/S0040-4039(01)82718-0

123.Kondo, K.; Umemoto, T.; Yako, Y.; Tunemoto, D. Tetrahedron Lett. 1978, 19, 3927-3930. doi:10.1016/S0040-4039(01)95100-7

124.Pfitzner, K. E.; Moffat, J. G. J. Am. Chem. Soc. 1965, 87, 5661-5670. doi:10.1021/ja00952a026

125.Brown, H. C.; Narsimhan, S. J. Org. Chem. 1982, 47, 1604-1606. doi:10.1021/jo00347a057

126. Deziel, R. Tetrahedron Lett. 1987, 28, 4371-4372. doi:10.1016/S0040-4039(00)96512-2

127. Tebbe, F. N.; Parshall, G. W.; Reddy, G. S. J. Am. Chem. Soc. 1978, 100, 3611-3613. doi:10.1021/ja00479a061

128. Newcomb, N. J.; Ya, F.; Vijn, R. J.; Hiemstra, H.; Speckamp, W. N. J. Chem. Soc., Chem. Commun. 1994, 767-768. doi:10.1039/C39940000767

129.Benhamou, M. C.; Etemad-Moghadam, G.; Speziale, V.; Lattes, A. Synthesis 1979, 891-892. doi:10.1055/s-1979-28864

130.Kende, A. S.; Smalley, T. L., Jr.; Huang, H. J. Am. Chem. Soc. 1999, 121, 7431-7432. doi:10.1021/ja991528a

131. Isostemofoline has been reported to be isolated in the laboratories of Prof. Yang Ye, Insititute of Materia Medica, Chinese Academy of Science in the reference above and has not been published yet.

132. Krapcho, A. P. Synthesis 1982, 893-914. doi:10.1055/s-1982-29991

133. Seebach, D.; Locher, R. Angew. Chem., Int. Ed. Engl. 1979, 18, 957-958. doi:10.1002/anie.197909571

134.Pelter, A.; Al-Bayati, R. I. H.; Ayoub, M. T.; Lewis, W.; Pardasani, P.; Hansel, R. J. Chem. Soc., Perkin Trans. 1 1987, 717-742. doi:10.1039/P19870000717

135. Knight, D. W.; Pattenden, G. J. Chem. Soc., Perkin Trans. 11975 635-640. doi:10.1039/P19750000635

136. Irie, H.; Masaki, N.; Ohno, R.; Osaki, K.; Taga, T.; Uyeo, S. J. Chem. Soc. D 1970, 1066. doi:10.1039/C29700001066
137.Ng, F. W.; Lin, H.; Danishefsky, S. J. J. Am. Chem. Soc. 2002, 124, 9812-9824. doi:10.1021/ja0204675

138.Lin, H.; Ng, F. W.; Danishefsky, S. J. Tetrahedron Lett. 2002, 43, 549-551. doi:10.1016/S0040-4039(01)02213-4

139. Ng, F. W.; Lin, H.; Chiu, P.; Danishefsky, S. J. J. Am. Chem. Soc. 2003, 125, 13303. doi:10.1021/ja0334558

140. Story, P. R. J. Org. Chem. 1961, 26, 287-290. doi:10.1021/jo01061a001

141. Klumpp, G. W.; Barnick, J. F. W. K.; Veefkind, A. H.; Bickelhaupt, F. Recl. Trav. Chim. Pays-Bas 1969, 88, 766-778. doi:10.1002/recl.19690880702

142. Cupas, C.; Watts, W. E.; von R. Schleyer, P. Tetrahedron Lett. 1964, 2503-2507. doi:10.1016/S0040-4039(00)70415-1

143.Luche, J.-L.; Gemal, A. L. J. Chem. Soc., Chem. Commun. 1978, 976-977. doi:10.1039/C39780000976

144.Beyerman, H. C.; Heiszwolf, G. L. J. Chem. Soc. 1963, 755-756.

145. Johnson, W. S.; Werthemann, L.; Bartlett, W. R.; Brocksom, T. J.; Li, T.-T.; Faulkner, D. J.; Perterson, M. R. J. Am. Chem. Soc. 1970, 92, 741-743. doi:10.1021/ja00706a074

146. Shiori, T.; Ninomiya, K.; Yamada, S. J. Am. Chem. Soc. 1972, 94, 6203-6205. doi:10.1021/ja00772a052

147. NInomiya, K.; Shiori, T.; Yamada, S. Tetrahedron 1974, 30 , 2151-2157. doi:10.1016/S0040-4020(01)97352-1

148.Felix, D.; Gschwend-Steen, K.; Wick, A. E.; Eschenmoser, A. Helv. Chim. Acta 1969, 52, 1030-1042. doi:10.1002/hlca.19690520418

149.Pappo, R.; Allen, D. S., Jr.; Lemieux, R. U.; Johnson, W. S. J. Org. Chem. 1956, 21, 478-479. doi:10.1021/jo01110a606

150. Griffith, W. P.; Ley, S. V.; Whitcombe, G. P.; White, A. D. J. Chem. Soc., Chem. Commun. 1987, 1625-1627. doi:10.1039/C39870001625

151. Confalone, P. N.; Huie, E. M. J. Org. Chem. 1987, 52, 79-83. doi:10.1021/jo00377a014

152.Lin, L.-Z.; Cordell, G. A.; Ni, C.-Z.; Clardy, J. Phytochemistry 1991, 30 , 1311-1315. doi:10.1016/S0031-9422(00)95223-3

153. Shimokawa, J.; Harada, T.; Yokoshima, S.; Fukuyama, T. J. Am. Chem. Soc. 2011, 133, 17634-17637. doi:10.1021/ja208617c

154.Shimokawa, J.; Harada, T.; Yokoshima, S.; Fukuyama, T. Pure Appl. Chem. 2012, 84, 1643-1650. doi:10.1351/PAC-CON-11-10-25

155. Achmatowicz, O., Jr.; Bukowski, P.; Szechner, B.; Zwierzchowska, Z.; Zamojski, A. Tetrahedron 1971, 27, 1973-1996. doi:10.1016/S0040-4020(01)98229-8

156. van den Heuvel, M.; Cuiper, A. D.; van der Deen, H.; Kellogg, R. M.; Feringa, B. L. Tetrahedron Lett. 1997, 38, 1655-1658. doi:10.1016/S0040-4039(97)00155-X

157.Kende, A. S.; Luzzio, M. J.; Mendoza, J. S. J. Org. Chem. 1990, 55, 918-924. doi:10.1021/jo00290a023

158. Yoshida, Y.; Sjimonishi, K.; Sakakura, Y.; Okada, S.; Aso, N.; Tanabe, Y. Synthesis 1999, 1633-1636. doi:10.1055/s-1999-3561

159. Kawabata, H.; Hayashi, M. Tetrahedron Lett. 2002, 43, 5645-5647. doi:10.1016/S0040-4039(02)01133-4

160. Kobayashi, S.; Tsuchiya, Y.; Mukaiyama, T. Chem. Lett. 1991, 20, 537-540. doi:10.1246/cl.1991.537

161. Krespki, L. R.; Jensen, K. M.; Heilmann, S. M.; Rasmussen, J. K.; Lynch, L. E. Synth. Commun. 1986, 16, 617-625. doi:10.1080/00397918608057730

162. Bredereck, H.; Simchen, G.; Rebsdat, S.; Kantlehner, W.; Horn, P.; Wahl, R.; Hoffmann, H.; Grieshaber, P. Chem. Ber. 1968, 101, 41-50. doi:10.1002/cber.19681010108 
163.Arnold, Z.; Zemlicka, J. Collect. Czech. Chem. Commun. 1959, 24, 2378-2384.

164.Arnold, Z.; Zemlicka, J. Collect. Czech. Chem. Commun. 1959, 24, 2385-2392.

165.Scott, W. J.; Stille, J. K. J. Am. Chem. Soc. 1986, 108, 3033-3040. doi:10.1021/ja00271a037

166.Su, Y.; Hu, Y.; Han, J.; Zheng, J.; Qi, J.; Jiang, T.; Pan, X.; She, X. J. Org. Chem. 2009, 74, 2743-2749. doi:10.1021/jo9000146

167.Jung, M. E.; Lyster, M. A. J. Chem. Soc., Chem. Commun. 1978, 315-316. doi:10.1039/C39780000315

168. Olah, G. A.; Narang, S. C.; Gupta, B. G. B.; Malhotra, R. Synthesis 1979, 61-62. doi:10.1055/s-1979-28558

169. Wender, P. A.; Hillemann, C. L.; Szymonifka, M. J. Tetrahedron Lett. 1980, 21, 2205-2208. doi:10.1016/0040-4039(80)80003-7

170.Evans, F. J.; Soper, C. J. Lloydia 1978, 41, 193.

171.Davies, H. M. L.; Calvo, R. L.; Townsend, R. J.; Ren, P.; Churchill, R. M. J. Org. Chem. 2000, 65, 4261-4268. doi:10.1021/jo991959b

172.Dabrah, T. T.; Kaneko, T.; Massefski, W., Jr.; Whipple, W. B. J. Am. Chem. Soc. 1997, 119, 1594-1598. doi:10.1021/ja961000v

173.Dabrah, T. T.; Harwood, H. J., Jr.; Huang, L. H.; Jankovich, N. D.; Kaneko, T.; Li, J. C.; Lindsey, S.; Mashier, P.; Subashi, T. A.; Therrien, M.; Watts, P. C. J. Antibiot. 1997, 50, 1-7. doi:10.7164/antibiotics.50.1

174. Vaswani, R. G.; Day, J. J.; Wood, J. L. Org. Lett. 2009, 11, 4532-4535. doi:10.1021/ol901746c

175.Caroll, A. R.; Hyde, E.; Smith, J.; Quinn, R. J.; Guymer, G.; Forster, P. I. J. Org. Chem. 2005, 70, 1096-1099. doi:10.1021/jo048439n

176.Tsuji, J.; Shimizu, I.; Minami, I.; Ohashi, Y. Tetrahedron Lett. 1982, 23, 4809-4812. doi:10.1016/S0040-4039(00)85719-6

177. Trost, B. M. Angew. Chem., Int. Ed. Engl. 1989, 28, 1173-1192. doi:10.1002/anie.198911731

178.Furrow, M. E.; Myers, A. G. J. Am. Chem. Soc. 2004, 126, 5436-5445. doi:10.1021/ja049694s

179. Kobayashi, S.; Hamada, T.; Manabe, K. Synlett 2001, 1140-1142. doi:10.1055/s-2001-15166

180. Takeda, K.; Nakane, D.; Takeda, M. Org. Lett. 2000, 2, 1903-1905. doi:10.1021/ol0059753

181.Albutt, A. D.; Ayer, W. A.; Brodie, H. J.; Johri, B. N.; Taube, H. Can. J. Microbiol. 1971, 17, 1401-1407. doi:10.1139/m71-223

182.Ayer, W. A.; Taube, H. Tetrahedron Lett. 1972, 13, 1917-1920. doi:10.1016/S0040-4039(01)84751-1

183. Ayer, W. A.; Taube, H. Can. J. Chem. 1973, 51, 3842-3854. doi:10.1139/v73-574

184.Ayer, W. A.; Lee, S. P. Can. J. Chem. 1979, 57, 3332-3337. doi:10.1139/v79-543

185.Ayer, W. A.; Carstens, L. L. Can. J. Chem. 1973, 51, 3157-3160. doi:10.1139/v73-470

186.Ayer, W. A.; Browne, L. A.; Mercer, J. R.; Taylor, D. R.; Ward, D. E. Can. J. Chem. 1978, 56, 717-721. doi:10.1139/v78-118

187. Ayer, W. A.; Yoshida, T.; van Schie, D. M. J. Can. J. Chem. 1978, 56, 2113-2120. doi:10.1139/v78-345

188. Ayer, W. A.; Nakashima, T. T.; Ward, D. E. Can. J. Chem. 1978, 56, 2197-2199. doi:10.1139/v78-360

189.Ayer, W. A.; Lee, S. P.; Nakashima, T. T. Can. J. Chem. 1979, 57, 3338-3343. doi:10.1139/v79-544

190.Swaminathan, S.; Narayanan, K. V. Chem. Rev. 1971, 71, 429-438. doi:10.1021/cr60273a001
191.Snider, B. B.; Rodini, D. J.; van Straten, J. J. Am. Chem. Soc. 1980, 102, 5872-5880. doi:10.1021/ja00538a028

192.Takeda, K.; Nakajima, A.; Takeda, M.; Yoshii, E.; Zhang, J.; Boeckmann, R. K., Jr. Org. Synth. 1999, 76, 199-213.

193. Gone, J. R.; Wallock, N. J.; Lindeman, S.; Donaldson, W. A. Tetrahedron Lett. 2009, 50, 1023-1025. doi:10.1016/j.tetlet.2008.12.051

194.Zhang, S.; Wang, J.; Xue, H.; Deng, Q.; Xing, F.; Ando, M. J. Nat. Prod. 2002, 65, 1927-1929. doi:10.1021/np0202632 See for two selected members of the guianolide family.

195.Zhang, S.; Zhao, M.; Bai, L.; Hasegawa, T.; Wang, J.; Wang, L.; Xue, H.; Deng, Q.; Xing, F.; Bai, Y.; Sakai, J.; Bai, J.; Koyanagi, R.; Tsukumo, Y.; Kataoka, R.; Nagai, K.; Hirose, K.; Ando, M. J. Nat. Prod. 2006, 69, 1425-1428. doi:10.1021/np068015j

196.Sarpong, R.; Su, J. T.; Stoltz, B. M. J. Am. Chem. Soc. 2003, 125, 13624-13625. doi:10.1021/ja037587c

197.Su, J. T.; Sarpong, R.; Stoltz, B. M.; Goddard, W. A., III. J. Am. Chem. Soc. 2004, 126, 24-25. doi:10.1021/ja037716p

198. Freeman, P. K.; Kuper, D. G. Chem. Ind. (London) 1965, 424-425.

199. Wolff, L. Justus Liebigs Ann. Chem. 1902, 325, 129-195. doi:10.1002/jlac.19023250202

200. Tucker, J. W.; Stephenson, C. R. J. Org. Lett. 2011, 13, 5468-5471. doi:10.1021/ol202178t

201.Padwa, A.; Krumpe, K. E.; Gareau, Y.; Chiacchio, U. J. Org. Chem. 1991, 56, 2523-2530. doi:10.1021/jo00007a047

202.Takada, Y.; Nomura, K.; Matsubara, S. Org. Lett. 2010, 12, 5204-5205. doi:10.1021/ol102237b

203. Mauleón, P.; Krinsky, J. L.; Toste, F. D. J. Am. Chem. Soc. 2009, 131, 4513-4520. doi:10.1021/ja900456m

204.Miki, K.; Ohe, K.; Uemura, S. J. Org. Chem. 2003, 68, 8505-8513. doi:10.1021/jo034841a

205. Gorin, D. J.; Watson, I. D. G.; Toste, F. D. J. Am. Chem. Soc. 2008, 130, 3736-3737. doi:10.1021/ja710990d

206. Garayalde, D.; Krüger, K.; Nevado, C. Angew. Chem., Int. Ed. 2011, 50, 911-915. doi:10.1002/anie.201006105

207.Jiménez-Núñez, E. J.; Raducan, M.; Lauterbach, T.; Molawi, K.; Solorio, C. R.; Echavarren, A. M. Angew. Chem., Int. Ed. 2009, 48, 6152-6155. doi:10.1002/anie.200902248

208. Gung, B. W.; Bailey, L. N.; Wosner, J. Tetrahedron Lett. 2010, 51, 2251-2253. doi:10.1016/j.tetlet.2010.02.099

209. Kusama, H.; Onizawa, Y.; Iwasawa, N. J. Am. Chem. Soc. 2006, 128, 16500-16501. doi:10.1021/ja0671924

210.Kim, S. Y.; Park, Y.; Chung, Y. K. Angew. Chem., Int. Ed. 2010, 49, 415-418. doi:10.1002/anie.200905361

211. Cao, Z.; Gagosz, F. Angew. Chem., Int. Ed. 2013, 52, 9014-9018. doi:10.1002/anie.201304497

212.Levin, S.; Nani, R. R.; Reisman, S. E. J. Am. Chem. Soc. 2011, 133, 774-776. doi:10.1021/ja110192b

213. Aoyagi, Y.; Yamazaki, A.; Nakatsugawa, C.; Fukaya, H.; Takeya, K.; Kawauchi, S.; Izumi, H. Org. Lett. 2008, 10, 4429-4432. doi:10.1021/ol801620u

214. Yamamoto, Y.; Arakawa, T.; Ogawa, R.; Itoh, K. J. Am. Chem. Soc. 2003, 125, 12143-12160. doi:10.1021/ja0358697

215.Bachmann, W. E.; Struve, W. S. Org. React. 1942, 1, 38-62.

216. Goddard-Boger, E. D.; Stick, R. V. Org. Lett. 2007, 9, 3797-3800. doi:10.1021/ol701581g

217.Boeckman, R. K., Jr.; Shair, M. D.; Vargas, J. R.; Stolz, L. A. J. Org. Chem. 1993, 58, 1295-1297. doi:10.1021/jo00058a001

218. Salmond, W. G.; Barta, M. A.; Havens, J. L. J. Org. Chem. 1978, 43, 2057-2059. doi:10.1021/jo00404a049 
219.Clark, D. L.; Chou, W. N.; White, J. B. J. Org. Chem. 1990, 55, 3975-3977. doi:10.1021/jo00300a005

220.Chou, W. N.; White, J. B.; Smith, W. B. J. Am. Chem. Soc. 1992, 114 4658-4667. doi:10.1021/ja00038a032

221.von Zezschwitz, P.; Voigt, K.; Lansky, A.; Noltemeyer, M.; de Meijere, A. J. Org. Chem. 1999, 64, 3806-3812. doi:10.1021/jo981496u

222.Xu, X.; Hu, W.-H.; Zavalij, P. Y.; Doyle, M. P. Angew. Chem., Int. Ed. 2011, 50, 11152-11155. doi:10.1002/anie.201105557

223.Lee, Y. R.; Hwang, J. C. Eur. J. Org. Chem. 2005, 1568-1577. doi:10.1002/ejoc.200400452

224.Doyle, M. P.; Hu, W.; Timmons, D. J. Org. Lett. 2001, 3, 3741-3744. doi:10.1021/ol016703i

225.Doyle, M. P.; Hu, W.; Timmons, D. J. Org. Lett. 2001, 3, 933-935. doi:10.1021/ol015600x

226. Doyle, M. P.; Yan, M.; Hu, W.; Gronenberg, L. S. J. Am. Chem. Soc. 2003, 125, 4692-4693. doi:10.1021/ja029745q

227.Müller, P.; Toujas, J.-L.; Bernardinelli, G. Helv. Chim. Acta 2000, 83, 1525-1534. doi:10.1002/1522-2675(20000705)83:7<1525::AID-HLCA1525>3.0.C $0 ; 2-1$

228. Müller, P.; Imogai, H. Helv. Chim. Acta 1999, 82, 315-322. doi:10.1002/(SICI)1522-2675(19990310)82:3<315::AID-HLCA315>3.0 .CO;2-T

229.Boeckman, R. K., Jr.; Reeder, M. R. J. Org. Chem. 1997, 62, 6456-6457. doi:10.1021/jo9712254

230.Boeckman, R. K., Jr.; Zhang, J.; Reeder, M. R. Org. Lett. 2002, 4, 3891-3894. doi:10.1021/ol0267174

231.Boeckman, R. K., Jr.; Genung, N. E.; Chen, K.; Ryder, T. R. Org. Lett. 2010, 12, 1628-1631. doi:10.1021/ol100397q

\section{License and Terms}

This is an Open Access article under the terms of the Creative Commons Attribution License (http://creativecommons.org/licenses/by/2.0), which permits unrestricted use, distribution, and reproduction in any medium, provided the original work is properly cited.

The license is subject to the Beilstein Journal of Organic Chemistry terms and conditions:

(http://www.beilstein-journals.org/bjoc)

The definitive version of this article is the electronic one which can be found at: doi:10.3762/bjoc. 10.14 